\title{
Prevalence of psychoactive substance USE AMONG STUDENTS ATTENDING YOUTH CORRECTIONAL CENTRES
}

\section{ROZPOWSZECHNIENIE UŻYWANIA SUBSTANCJI PSYCHOAKTYWNYCH WŚRÓD PODOPIECZNYCH MEODZIEŻOWYCH OŚRODKÓW SOCJOTERAPEUTYCZNYCH I WYCHOWAWCZYCH}

\author{
Jakub Greń ID, Krzysztof Jan Bobrowski ID, Krzysztof Ostaszewski ID, Agnieszka Pisarska ID \\ Institute of Psychiatry and Neurology, Public Health Department, Youth Prevention Unit “Pro-M", Warsaw, Poland \\ Instytut Psychiatrii i Neurologii, Zakład Zdrowia Publicznego, Pracownia Profilaktyki Młodzieżowej „Pro-M”, Warszawa, Polska
}

Alcohol Drug Addict 2019; 32 (4): 267-290

DOI: https://doi.org/10.5114/ain.2019.94016

\begin{abstract}
Introduction: Development of effective strategies to prevent harm associated with youth substance use requires reliable data on its prevalence. To date, Polish population studies in this regard have not included youth from at-risk groups. This study aimed at examining the prevalence of substance use among Polish students attending special educational centres for young people at risk of social maladjustment i.e. youth sociotherapy centres (MOS) and youth correctional centres (MOW).

Material and methods: The random sample consists of students attending educational centres for at-risk youth in Poland $(n=1721)$. Data was
\end{abstract}

\section{Streszczenie}

Wprowadzenie: Opracowanie skutecznych strategii przeciwdziałania szkodom związanym z używaniem przez młodzież substancji psychoaktywnych wymaga znajomości rozpowszechnienia tego zjawiska. Dotychczasowe polskie badania populacyjne w tym zakresie nie obejmowały młodzieży $\mathrm{z}$ grup podwyższonego ryzyka. Celem tego badania była obserwacja i analiza rozpowszechnienia używania substancji psychoaktywnych wśród wychowanków placówek dla młodzieży zagrożonej niedostosowaniem społecznym, czyli młodzieżowych ośrodków socjoterapii (MOS) i młodzieżowych ośrodków wychowawczych (MOW).

Materiał i metody: Badaną grupę stanowili podopieczni dobranych losowo MOS i MOW z całego

Correspondence to/Adres do korespondencji: Jakub Greń, Zakład Zdrowia Publicznego, Pracownia Profilaktyki Młodzieżowej „Pro-M”, Instytut Psychiatrii i Neurologii, ul. Sobieskiego 9, 02-957 Warszawa, Polska, phone: +48 224582 630, e-mail: jgren@ipin.edu.pl

Authors' contribution/Wkład pracy autorów: Study design/Koncepcja badania: J. Greń, K. Ostaszewski, A. Pisarska, K.J. Bobrowski; Data collection/Zebranie danych: A. Pisarska, J. Greń; Statistical analysis/Analiza statystyczna: J. Greń; Data interpretation/Interpretacja danych: J. Greń, K. Ostaszewski; Acceptance of final manuscript version/Akceptacja ostatecznej wersji pracy: J. Greń, K.J. Bobrowski, K. Ostaszewski, A. Pisarska; Literature search/Przygotowanie literatury: J. Greń, K.J. Bobrowski; Funds collection/Pozyskanie środków (finansowania): A. Pisarska, K. Ostaszewski.

No ghostwriting and guest authorship declared./Nie występują zjawiska ghostwriting i guest authorship.

Submitted/Otrzymano: 24.09.2019 • Accepted/Przyjęto do druku: 17.12.2019

(C) 2019 Institute of Psychiatry and Neurology. Production and hosting by Termedia sp. z o.o.

This is an open access article under the CC BY-NC-ND license (http://creativecommons.org/licenses/by-nc-nd/4.0/) 
collected with self-administered questionnaire during schoollessons. Analyses of prevalence were conducted separately in two age groups: 12-15 $(n=682)$ and $16-19$ years of age $(n=1039)$. Gender and type of centre differences were examined by $\chi^{2}$ test. Furthermore, the results of our study have been compared with the ESPAD study results.

Results: Results indicated high prevalence of substance use among young people attending special educational centres. In both age groups analysed, prevalence indicators were higher among students attending MOW (compared to MOS), and among females (than males). Alcohol use prevalence was similar to alcohol use among youth from the general population, but prevalence of risky patterns of substance use (drunkenness, daily smoking, using illegal and new psychoactive substances) was much higher among youth attending both types of special educational centres.

Discussion: Very high substance use indicators among youth from special educational centres might be associated with these youths exposition to psychosocial risk factors such as substance use among peers and adults in the immediate social environment.

Conclusions: Results of our study support the need for preventive interventions focused on reducing the risks and harm associated with substance use among young people at risk of social maladjustment. Periodical continuation of similar studies to monitor the prevalence of these behaviours is recommended.

Keywords: Psychoactive substance use, Prevalence, Youth at-risk kraju ( $n=1721)$. Dane zbierano za pomocą audytoryjnych badań ankietowych. Analizy rozpowszechnienia używania substancji prowadzono $\mathrm{w}$ dwóch grupach wiekowych: $12-15$ lat $(n=682)$ oraz $16-19$ lat $(n=1039)$. Do zbadania różnic w rozpowszechnieniu używania substancji psychoaktywnych ze względu na płeć oraz rodzaj ośrodka wykorzystano test $\chi^{2}$. Ponadto uzyskane wyniki zestawiono $\mathrm{z}$ wynikami badań populacji ogólnej młodzieży szkolnej (ESPAD).

Wyniki: Wyniki wskazują na znaczne rozpowszechnienie używania substancji psychoaktywnych wśród podopiecznych MOS i MOW. W obydwu grupach wiekowych wskaźniki używania większości $\mathrm{z}$ analizowanych substancji były wyższe wśród wychowanków MOW (w porównaniu z MOS), a także wśród dziewcząt (w porównaniu z chłopcami). Wskaźniki picia alkoholu były porównywalne $\mathrm{z}$ wynikami populacji generalnej młodzieży. Ryzykowne wzory używania substancji psychoaktywnych (upijanie się, codziennie palenie papierosów, używanie substancji nielegalnych i nowych substancji psychoaktywnych) były jednak znacznie bardziej rozpowszechnione wśród podopiecznych MOS/MOW.

Omówienie: Bardzo wysokie wskaźniki używania substancji psychoaktywnych mogą mieć związek $\mathrm{z}$ ekspozycją młodzieży $\mathrm{z}$ obydwu rodzajów placówek na silne społeczne czynniki ryzyka, takie jak używanie substancji przez rówieśników i dorosłych z najbliższego otoczenia.

Wnioski: Wyniki naszego badania potwierdzają potrzebę wdrażania interwencji profilaktyczno-terapeutycznych ukierunkowanych na zapobieganie oraz ograniczanie ryzyka i szkód związanych z używaniem substancji psychoaktywnych wśród młodzieży z MOS i MOW. Rekomendowane jest okresowe powtarzanie tego typu badań w celu monitorowania rozpowszechnienia tych zachowań.

Słowa kluczowe: używanie substancji psychoaktywnych, rozpowszechnienie, młodzież z grupy ryzyka

\section{- INTRODUCTION}

Young people are exposed to serious health, social and educational risks as users of psychoactive substances [1]. The results of ESPAD population studies on school children [2] indicate that over $40 \%$ of $17-18$ year-olds have used cannabis in their lifetime, about $7 \%$ amphetamine and in-

\section{- WPROWADZENIE}

Zjawisko używania przez młodzież substancji psychoaktywnych niesie ze sobą poważne zagrożenia zdrowotne, społeczne i wychowawcze [1]. Wyniki populacyjnych badań młodzieży szkolnej ESPAD [2] wskazują, że ponad 40\% 17-18-latków w ciągu swojego życia używało przetworów konopi, ok. $7 \%$ odurzało się amfetaminą i substancjami 
halants, over 5\% LSD or other hallucinogens and about $4 \%$ have tried stimulants, like cocaine, ecstasy or methamphetamine. In the younger group (15-16 year-olds), around $10-12 \%$ declared they had used novel psychoactive substances (NPS) at least once in their lives. The prevalence of the use of most of these illegal substances was higher among boys than girls. Moreover, similar percentages of adolescents using different psychoactive substances were also noted in other nationwide population studies [3], which confirms its high prevalence in our country.

In addition to the health consequences and legal problems, drinking alcohol, smoking tobacco and using other psychoactive substances can also disrupt the developmental processes leading up to the transition from adolescence to adulthood $[4,5]$. This applies primarily to those teenagers who, due to unfavourable life circumstances and the severity of individual and environmental risk factors, are particularly prone to engaging in risky behaviours and, as a consequence, are exposed to experience related harm $[5,6]$. In Poland, young people who manifest learning difficulties and disrupted social functioning as well as anti-social behaviour or mental health problems, can be referred to one of two institutions offering special organisation of education $[7,8]$. Youth sociotherapy centres (MOS) receive young people at risk of social maladjustment at the request of parents or legal guardians. In contrast, youth educational centres (MOW), are intended for socially maladjusted young people that are admitted on the basis of a family court ruling. A broader presentation of the specifics of these centres is included in the article by Pisarska et al. [9].

In order to prepare effective strategies that prevent harm and other problems related to psychoactive substance use, it is necessary to gain knowledge of the prevalence and determinants of their use. Therefore, over the past three decades, we have been observing significant development of research aimed at monitoring indicators of alcohol, tobacco and illegal use as well as associated risk/protective factors [10]. Examples of international studies that include also Polish youth are the European School Survey Project on Alcohol and wziewnymi (inhalantami), ponad 5\% używało LSD lub innych halucynogenów, a ok. $4 \%$ próbowało takich stymulantów, jak kokaina, ecstasy czy metamfetamina. Z kolei w młodszej grupie (15-16-latków) ok. 10-12\% młodzieży deklarowało, że przynajmniej raz w życiu używało nowych substancji psychoaktywnych (NSP), czyli tzw. dopalaczy. Przy czym rozpowszechnienie używania większości $\mathrm{z}$ tych nielegalnych substancji było większe wśród chłopców niż dziewcząt. Co więcej, podobne odsetki młodzieży używającej różnych substancji psychoaktywnych odnotowano także w innych ogólnopolskich badaniach populacyjnych młodzieży [3], co potwierdza znaczne rozpowszechnienie tego zjawiska w naszym kraju.

Poza konsekwencjami zdrowotnymi i problemami prawnymi picie alkoholu, palenie tytoniu i używanie innych substancji psychoaktywnych może również zakłócić procesy rozwojowe składające się na przejście młodych ludzi do dorosłości [4, 5]. Zagrożenie to dotyczy przede wszystkim tych nastolatków, którzy ze względu na niekorzystną sytuację życiową oraz nasilenie indywidualnych i środowiskowych czynników ryzyka są szczególnie skłonni do podejmowania zachowań ryzykownych, a w konsekwencji są narażeni na doświadczanie związanych z nimi szkód $[5,6]$. W Polsce młodzież, która przejawia trudności w nauce i funkcjonowaniu społecznym oraz zachowania antyspołeczne lub problemy zdrowia psychicznego, może być kierowana do jednego $\mathrm{z}$ dwóch typów placówek oferujących specjalną organizację nauki i wychowania $[7,8]$. Pierwszy z nich - młodzieżowe ośrodki socjoterapii (MOS) - jest przeznaczony dla młodzieży zagrożonej niedostosowaniem społecznym; młodzież trafia tam na wniosek rodziców lub opiekunów prawnych. Natomiast do młodzieżowych ośrodków wychowawczych (MOW), przeznaczonych dla młodzieży społecznie niedostosowanej, podopieczni są przyjmowani na podstawie decyzji sądu rodzinnego. Szersze przedstawienie specyfiki tych ośrodków zawarto w artykule Pisarskiej i wsp. [9].

W celu opracowania skutecznych strategii przeciwdziałania szkodom i innym problemom związanym $\mathrm{z}$ substancjami psychoaktywnymi konieczna jest wiedza na temat rozpowszechnienia oraz uwarunkowań używania tych substancji. $\mathrm{Z}$ tego powodu w ciągu ostatnich trzech dekad obserwujemy znaczący rozwój badań, których celem jest monitorowanie wskaźników używania alkoholu, tytoniu oraz narkotyków, jak i powiązanych z tymi zachowaniami czynników ryzyka/chroniących [10]. Przykładami badań o zasięgu międzyna- 
Other Drugs (ESPAD) [2] and Health Behaviour in School-aged Children (HBSC) [11]. In addition, at the national level, there is the study "Consumption of psychoactive substances by young people" carried out by the CBOS Foundation [3]. The Mokotow [12] and Ilawa studies [13], and those carried out in Krakow [14, 15 ], should be also mentioned among the research conducted on samples from the population of local young people. Thanks to their reliability and standardised methodology, these studies allow us not only to measure the prevalence of psychoactive substance use and other risky behaviours among young people, but also to track developing trends over time. These studies, however, include only young people attending regular schools.

Thus, despite the recognition of the need to include youth from high-risk groups of special concern [16-18], there are very few empirical studies on the prevalence of psychoactive substance use in these groups. This is the case not only for Poland as adolescents in educational institutions other than the regular schools are omitted in foreign research as well. Review of available literature on this subject has provided us with several papers: from the Netherlands [19, 20], the UK [5, 21], USA [22, 23], New Zealand [24], Hong Kong [25] and the former Yugoslavia [26]. The overall findings from these studies clearly show that young people referred to institutions of this kind use psychoactive substances much more often than young people from the general population. For example, a study that included a small subgroup of young people attending MOS and MOW in Warsaw indicated that the prevalence of psychoactive substance use and other risky behaviours were up to several times higher than among young people from regular schools [27]. In the study conducted in the UK [21] it was found that, compared to regular school students, young people studying in special education institutions reported a significantly higher level of psychoactive substance use, frequent poly-substance use (i.e. simultaneous use of several substances) and more frequent risky sexual behaviour. rodowym, które obejmują także polską młodzież, są European School Survey Project on Alcohol and Other Drugs (ESPAD) [2] oraz Health Behaviour in School-aged Children (HBSC) [11]. Ponadto na poziomie krajowym prowadzone są badania Konsumpcja substancji psychoaktywnych przez młodzież Fundacji CBOS [3]. Z kolei wśród badań prowadzonych na lokalnych próbach młodzieży należy wymienić badania mokotowskie [12], badania iławskie [13] i badania realizowane w Krakowie [14, 15]. Dzięki swojej powtarzalności i wystandaryzowanej metodologii pozwalają one nie tylko mierzyć rozpowszechnienie używania substancji psychoaktywnych oraz innych zachowań ryzykownych młodzieży, lecz także śledzić ich trendy w czasie. Wymienione badania obejmują jednak tylko młodzież uczęszczającą do szkół ogólnodostępnych.

A zatem, pomimo rozpoznania potrzeby objęcia młodzieży $\mathrm{z}$ grup podwyższonego ryzyka szczególną uwagą [16-18], badania empiryczne dotyczące rozpowszechnienia używania substancji psychoaktywnych w tych grupach są bardzo nieliczne. Sytuacja ta nie jest jednak specyficzna jedynie dla Polski, gdyż podopieczni placówek oświatowych innych niż szkoły ogólnodostępne są pomijani także $\mathrm{w}$ badaniach zagranicznych. Z przeglądu dostępnych publikacji dotyczących tej problematyki odnotowano kilka prac pochodzących z Holandii [19, 20], Wielkiej Brytanii [5, 21], USA [22, 23], Nowej Zelandii [24], Hongkongu [25] oraz dawnej Jugosławii [26]. Ogólne wyniki tych badań jednoznacznie wskazują, że młodzież kierowana do takich placówek używa substancji psychoaktywnych znacznie częściej niż młodzież z populacji generalnej. Na przykład $\mathrm{w}$ badaniu uwzględniającym jedynie małą podgrupę młodzieży będącej pod opieką MOS i MOW w Warszawie wykazano, że wskaźniki rozpowszechnienia używania substancji psychoaktywnych oraz innych zachowań ryzykownych były wśród wychowanków tych placówek od kilku do kilkunastu razy wyższe niż wśród młodzieży ze szkół ogólnodostępnych [27]. Z kolei w badaniach zrealizowanych w Wielkiej Brytanii [21] stwierdzono, że w porównaniu z uczniami szkół ogólnodostępnych młodzież ucząca się w placówkach kształcenia specjalnego raportowała znacznie wyższy poziom używania substancji psychoaktywnych, częstą politoksykomanię (czyli jednoczesne 
Most of previous studies involving adolescents from high-risk groups included only small samples from single cities or regions $[26,27]$ were conducted a long time ago $[22,28]$ or used only qualitative methods [29]. Therefore young people from high-risk groups, including MOS and MOW students are under-represented in population studies [19], which results in only a limited knowledge of the specifics of their behaviour and health condition [21].

Problems resulting from the concentration of research on the general population of school children have already been indicated earlier also by Polish researchers [27, 29]. However, no comprehensive, national-scale study on the use of psychoactive substances that would consider the representation of high-risk youth, has yet been carried out. Therefore this study was designed to: 1) measure the prevalence of a consuming alcohol, smoking tobacco and the use of other psychoactive substances among MOS and MOW students; 2) analyse the diversity of prevalence of various psychoactive substances use among these young people by age, gender and type of educational centre and 3) verify how far the prevalence of the use of particular psychoactive substances deviates from the results of the general school population in Poland.

\section{- MATERIAL AND METHODS}

The study presented here was conducted as an auditory, self-administered survey among MOS and MOW students. This study was part of a larger project that goals and metodology were described in the introductory article (Pisarska et al.) [9] published in this issue of the quarterly Alcoholism and Drug Addiction. This article is therefore limited to the necessary information on the study method, i.e. the description of the research sample, survey questions used in these analyses and indicators of specific psychoactive substance use. używanie kilku substancji) i częstsze podejmowanie ryzykownych zachowań seksualnych.

Większość z dotychczasowych badań z udziałem młodzieży $z$ grup podwyższonego ryzyka obejmowała jedynie małe próby, pochodzące $z$ jednego miasta lub regionu $[26,27]$, została dość dawno zrealizowana $[22,28]$ lub wykorzystywała wyłącznie metody jakościowe [29]. Młodzi ludzie z grup podwyższonego ryzyka, do których należą podopieczni MOS i MOW, są więc niedostatecznie reprezentowani w badaniach populacyjnych [19], czego efektem jest ograniczona wiedza na temat charakterystyki ich zachowań oraz kondycji zdrowotnej [21].

Problemy wynikające z koncentracji badaczy na ogólnej populacji młodzieży szkolnej były już wskazywane wcześniej także przez polskich badaczy [27, 29]. Dotąd nie udało się jednak przeprowadzić zakrojonych na ogólnokrajową skalę badań dotyczących używania substancji psychoaktywnych, które uwzględniałyby reprezentację młodzieży z grup podwyższonego ryzyka. $Z$ tego powodu niniejsze badanie miało na celu: 1) pomiar rozpowszechnienia picia alkoholu, palenia tytoniu oraz używania innych substancji psychoaktywnych wśród podopiecznych MOS i MOW; 2) analizę zróżnicowania rozpowszechnienia używania poszczególnych substancji psychoaktywnych wśród tej młodzieży ze względu na wiek, płeć oraz typ placówki, a także 3) sprawdzenie, jak dalece rozpowszechnienie używania poszczególnych substancji psychoaktywnych odbiega od wyników ogólnej populacji młodzieży szkolnej w Polsce.

\section{- MATERIAt I METODY}

Prezentowane badanie zostało przeprowadzone $\mathrm{z}$ wykorzystaniem audytoryjnych badań ankietowych wśród podopiecznych placówek MOS i MOW. Badanie to było częścią większego projektu, którego cele, założenia oraz metodologia zostały opisane $\mathrm{w}$ artykule wprowadzającym Pisarskiej i wsp. [9], opublikowanym w niniejszym numerze kwartalnika Alkoholizm i Narkomania. W tym artykule ograniczono się więc jedynie do niezbędnych informacji z zakresu metody, tj. opisu próby badawczej, pytań ankietowych wykorzystanych w niniejszych analizach i wskaźników używania poszczególnych substancji psychoaktywnych. 


\section{Sample}

Participants of this study came from about $40 \%$ of all MOS and MOW facilities in Poland (30 MOS and $35 \mathrm{MOW}$ ). The survey was completed by 2063 pupils, which constituted 76\% of the randomly selected sample. The questionnaires completed by 333 respondents were excluded due to a significant lack of data or responses indicating that the study was not taken seriously. Since the age factor plays an important role in the prevalence of substance use during adolescence, the analyses presented in this article were conducted on two age groups. The younger group was $12-15$ years old $(n=682)$ and the older 16-19 $(n=1039)$. In total, 1721 out of 1730 respondents were analysed as 9 of the respondents did not answer the question about age. The applied distinction corresponds to knowledge about the stages of adolescence [30]. The younger age group includes teenagers in the early phase, while the older respondents were in the late phase of the adolescence. This division also enabled us to compare the results of our study with that of ESPAD: the younger group (average age $=14.5 ; \mathrm{SD}=0.71$ ) with the results of ESPAD for the group of 15-yearolds; whereas the older group (mean age $=16.6$; $\mathrm{SD}=0.67)$ with ESPAD results for the 17 -yearold group.

\section{Data analysis}

Descriptive analyses were used in order to assess the prevalence of the use of various psychoactive substances among the study participants. The analysis of the variation of results in terms of gender and type of educational centre was conducted using the $\chi^{2}$ test, with a statistical significance threshold of $p<0.05$. The use of psychoactive substances in the last 12 months was used as a standard to compare the results obtained with that of the ESPAD study. The use of statistical tests in this comparison was not possible for technical reasons. Data analyses were performed using statistical software SPSS v. 24.

\section{Research tools and indicators}

The questions on the frequency of drinking alcohol, getting drunk and using cannabis/ hashish and related scales used were derived from the ESPAD study $[2,31]$. Similarly to the

\section{Próba}

Uczestnicy badania pochodzili z ok. 40\% wszystkich placówek MOS i MOW w Polsce (30 MOS i 35 MOW). Ankietę wypełniło 2063 podopiecznych, co stanowiło $76 \%$ wylosowanej próby. Ankiety 333 osób zostały wyłączone z próby ze względu na znaczące braki danych lub odpowiedzi świadczące o niepoważnym potraktowaniu badania. Ze względu na to, że czynnik wieku odgrywa istotną rolę w rozpowszechnieniu używania substancji w okresie dojrzewania, analizy $\mathrm{w}$ niniejszej pracy były prowadzone w dwóch grupach wiekowych. Młodsza grupa obejmowała młodzież w wieku 12-15 lat $(n=682)$, a starsza - w wieku 16-19 lat $(n=1039)$. Łącznie analizami objęto 1721 spośród 1730 badanych, gdyż 9 respondentów nie udzieliło odpowiedzi na pytanie o wiek. Zastosowany podział koresponduje $\mathrm{z}$ wiedzą na temat faz okresu dojrzewania [30]. Młodsza grupa wiekowa obejmuje nastolatków $\mathrm{w}$ fazie wczesnej, a starsza grupa w fazie późnej adolescencji. Podział ten umożliwił również zestawienie wyników niniejszych badań $\mathrm{z}$ wynikami badań ESPAD: młodszą grupę (średnia wieku $=14,5$ roku; $\mathrm{SD}=0,71) \mathrm{z}$ wynikami badań ESPAD dla grupy 15-latków, natomiast grupę starszą (średnia wieku $=16,6$ roku; $\mathrm{SD}=0,67) \mathrm{z}$ wynikami badań ESPAD dla grupy 17-latków.

\section{Analiza danych}

Do oceny rozpowszechnienia używania poszczególnych substancji psychoaktywnych wśród badanej młodzieży wykorzystano analizy opisowe. Analizę zróżnicowania uzyskanych wyników ze względu na płeć i typ placówki przeprowadzono za pomocą testu $\chi^{2} \mathrm{z}$ progiem istotności statystycznej $p<0,05$. Do zestawienia otrzymanych wyników $\mathrm{z}$ wynikami badań ESPAD posłużono się porównywalnym w obu badaniach wskaźnikiem - używanie substancji psychoaktywnych w ciągu ostatnich 12 miesięcy. Zastosowanie testów statystycznych $\mathrm{w}$ tym zestawieniu $\mathrm{z}$ przyczyn technicznych nie było możliwe. Analizy danych dokonano za pomocą oprogramowania statystycznego SPSS v. 24.

\section{Narzędzia i wskaźniki badawcze}

Zastosowane $\mathrm{w}$ niniejszym badaniu pytania i skale dotyczące częstości picia alkoholu, upijania się oraz używania przetworów konopi zostały zaczerpnięte $\mathrm{z}$ badań ESPAD [2, 31]. Na ich podstawie, analogicznie do pomiaru częstości używa- 
latter measure, a scale of the frequency of NPS use was also developed. Meanwhile, questions and research scales regarding smoking cigarettes, the use of e-cigarettes and other psychoactive substances were derived from the Mokotow studies [12].

\section{Alcohol use and drunkenness scales}

To measure the prevalence of alcohol use, the questions about the frequency of alcohol consumption in the last 12 months and 30 days: $O n$ how many occasions (if any), have you had any alcoholic beverage to drink, i.e. beer, wine or vod$k a$ ? were used. To measure the frequency of getting drunk, the question On how many occasions (if any) have you been intoxicated from drinking beer, wine or vodka? was used. Answers to both ranged from "1" = "I did not drink"/"I did not get drunk" to " 7 " = "40 or more times". Based on the above, four dichotomous indicators were constructed, which were used to analyse the data on: drinking alcohol and getting drunk at least 1-2 times in the last 30 days and in the last 12 months prior to the study.

\section{The tobacco and e-cigarettes use scales}

In order to measure the frequency of using the traditional cigarettes and the e-cigarettes, two questions were used: Do you smoke cigarettes? and Do you use e-cigarettes or IQOS? In both cases respondents had a choice of: "1" = "no", "2" = "yes, several times a year", " 3 " = "yes, several times a month", “4” = "yes, several times a week" and " 5 " = "yes, every day" as answers. Two indicators were used for the analysis: "smoking cigarettes at least several times a year" and "daily cigarette smoking". Analogical indicators were used to analyse the prevalence of e-cigarette use.

\section{The scales for measure other psychoactive} substance use

Two questions were used to measure the prevalence of other psychoactive substance use: one on the frequency of illegal drug use in the last 12 months (Have you used narcotic substances in the last year?), with answers from " 1 " = "no, I did not", to " 5 " = "yes, more than a dozen times", as well as the related question about the type of substances used (If you answered "yes" to nia marihuany i haszyszu, opracowano również własną skalę do pomiaru częstości używania NSP. Z kolei pytania i skale badawcze dotyczące palenia papierosów, używania e-papierosów i innych substancji psychoaktywnych zaczerpnięto z badań mokotowskich [12].

\section{Pomiar picia alkoholu i upijania się}

Do pomiaru rozpowszechnienia picia alkoholu wykorzystano dwa pytania - o częstość picia alkoholu w ciągu ostatnich 12 miesięcy i w ostatnich 30 dniach: Ile razy, jeśli $w$ ogóle, zdarzyło Ci się pić jakiś napój alkoholowy, tzn. piwo, wino lub wódkę?, natomiast do pomiaru częstości upijania się wykorzystano analogiczne pytanie: Ile razy, jeśli w ogóle, zdarzyło Ci się upić piwem, winem lub wódką? Możliwe odpowiedzi na obydwa pytania obejmowały skalę od „1” = „nie piłem/łam”/,nie upiłem/łam się" do ",7” = „40 lub więcej razy”. Na podstawie powyższych pytań skonstruowano cztery dychotomiczne wskaźniki, które wykorzystano do analizy danych, dotyczące picia alkoholu oraz upijania się przynajmniej 1-2 razy w ciągu ostatnich 30 dni i 12 miesięcy przed badaniem.

\section{Pomiar palenia tytoniu i używania e-papierosów}

Do pomiaru rozpowszechnienia palenia tytoniu wykorzystano dwa pytania o częstość palenia papierosów tradycyjnych oraz używania e-papierosów: Czy palisz papierosy? i Czy używasz e-papierosów lub IQOS? W obydwu pytaniach respondenci mieli do wyboru odpowiedzi: „1” = "nie”, „2” = „tak, kilka razy w roku”, „3” = „tak, kilka razy w miesiącu”, „4" = „tak, kilka razy w tygodniu” oraz ,,$"$ = „tak, codziennie”. Do analiz wykorzystano dwa wskaźniki: „palenie papierosów przynajmniej kilka razy w roku” oraz „codzienne palenie papierosów”. Analogiczne wskaźniki zastosowano do analizy rozpowszechnienia używania e-papierosów.

\section{Pomiar używania innych substancji psychoaktywnych}

Do pomiaru rozpowszechnienia używania innych substancji psychoaktywnych wykorzystano dwa pytania: o częstość używania środków narkotyzujących w ciągu ostatnich 12 miesięcy (Czyw ciagu ostatniego roku zdarzyło się, że używałeś/łaś środków narkotyzujacych?), z odpowiedziami od „1” = „nie 
the previous question, please indicate what were these drugs). On the second question, respondent could mark the answers using a list of 14 psychoactive substances, including: marijuana and hashish; NPS; LSD or other hallucinogens; psychotropic, sedatives, hypnotics drugs; amphetamine; mephedrone; heroin, "brown sugar" or a poppy brew known as "compote"; cocaine or crack; ecstasy or MDMA; anabolic steroids; GHB or GBL; glues, solvents, etc.; codeine. The overall indicator "I used at least 1-2 times in the last year" was applied to analyse the prevalence of drug use, while the answers to the second question were used to analyse the prevalence of using particular substances (at least 1-2 times in the last year).

\section{The cannabis/hashish and NPS use scales}

A question about the use of substances in the last 30 days prior to the study were used to analyse the prevalence of cannabis and NPS use. This data were derived from the answers to two questions: On how many occasions (if any), have you used marijuana or hashish? and On how many times (if any) have you used "boosters" [slang name of NPS]? The answers included: from " 1 " = "I did not use" to "7" = "40 or more times". The "use at least 1-2 times in the last 30 days" indicator was applied to assess the prevalence of using these substances. It should be added that mephedrone is also included in the NPS, but due to its widespread use, it was listed separately in this study.

\section{- RESUlts}

\section{Alcohol use and drunkenness}

The results presented in Table I indicate the widespread prevalence of alcohol use and drunkenness episodes among young people from MOS and MOW. In the younger group, about $80 \%$ of respondents had drunk alcohol in the last 12 months before the study and $70 \%$ had got drunk, while in the older group it was about $90 \%$ and $80 \%$ respectively. If we narrow down the measurement to the last 30 days prior to the survey, these percentages are about $50 \%$ and $40 \%$ in the younger and $56.5 \%$ and $45 \%$ in the older students of MOS and MOW respectively. At the same time, zdarzyło się”, do „„” = „tak, więcej niż kilkanaście razy", a także powiązane $\mathrm{z}$ tym pytanie o rodzaj używanych substancji (Jeżeli na poprzednie pytanie odpowiedziałeś/taś „tak” (używateś/taś), to zaznacz, jakie to były środki). W przypadku drugiego pytania respondent mógł zaznaczyć odpowiedzi, posługując się listą 14 substancji psychoaktywnych, w tym: marihuana i haszysz; „,dopalacze”; LSD lub inne halucynogeny; leki psychotropowe, uspokajające, nasenne; amfetamina; mefedron; heroina, brown sugar lub „kompot”; kokaina lub crack; ecstasy lub MDMA; sterydy anaboliczne; GHB lub GBL; kleje, rozpuszczalniki, itp.; kodeina. Do analiz rozpowszechnienia używania narkotyków wykorzystano ogólny wskaźnik „używałem/używałam przynajmniej 1-2 razy w ciągu ostatniego roku". Z kolei odpowiedzi na drugie pytanie posłużyły do analizy rozpowszechnienia używania poszczególnych substancji (przynajmniej 1-2 razy w ciągu ostatniego roku).

\section{Pomiar używania przetworów konopi i NSP}

Do analizy rozpowszechnienia używania przetworów konopi i NSP wykorzystano dodatkowo pytanie dotyczące używania tych substancji w ciągu ostatnich 30 dni przed badaniem. Dane te uzyskano w odpowiedzi na dwa pytania: Ile razy, jeśli w ogóle, zdarzyło Ci się używać marihuany lub haszyszu? oraz Ile razy, jeśli w ogóle, zdarzyło Ci się używać $t z w$. dopalaczy? Odpowiedzi uwzględniały: od „1" = „nie używałem/łam” do „7” = „40 lub więcej razy". Do analiz rozpowszechnienia tych substancji wykorzystano wskaźnik „używałem/ używałam przynajmniej 1-2 razy w ciągu ostatnich 30 dni”. Należy dodać, że mefedron jest również zaliczany do NSP, jednak ze względu na duże rozpowszechnienie jego używania w tym badaniu został wymieniony osobno.

\section{- WYNIKI}

\section{Picie alkoholu i upijanie się}

Przedstawione w tabeli I wyniki wskazują na znaczące rozpowszechnienie picia alkoholu oraz upijania się wśród badanej młodzieży z MOS i MOW. W grupie młodszej, w ciągu ostatnich 12 miesięcy przed badaniem, alkohol piło ok. $80 \%$ badanych, a $70 \%$ upiło się, natomiast w grupie starszej było to odpowiednio ok. $90 \%$ oraz $80 \%$. Jeśli zawęzimy pomiar do ostatnich 30 dni przed badaniem, odsetki te wynoszą odpowiednio ok. $50 \%$ i $40 \%$ w grupie młodszej oraz 56,5\% i $45 \%$ 


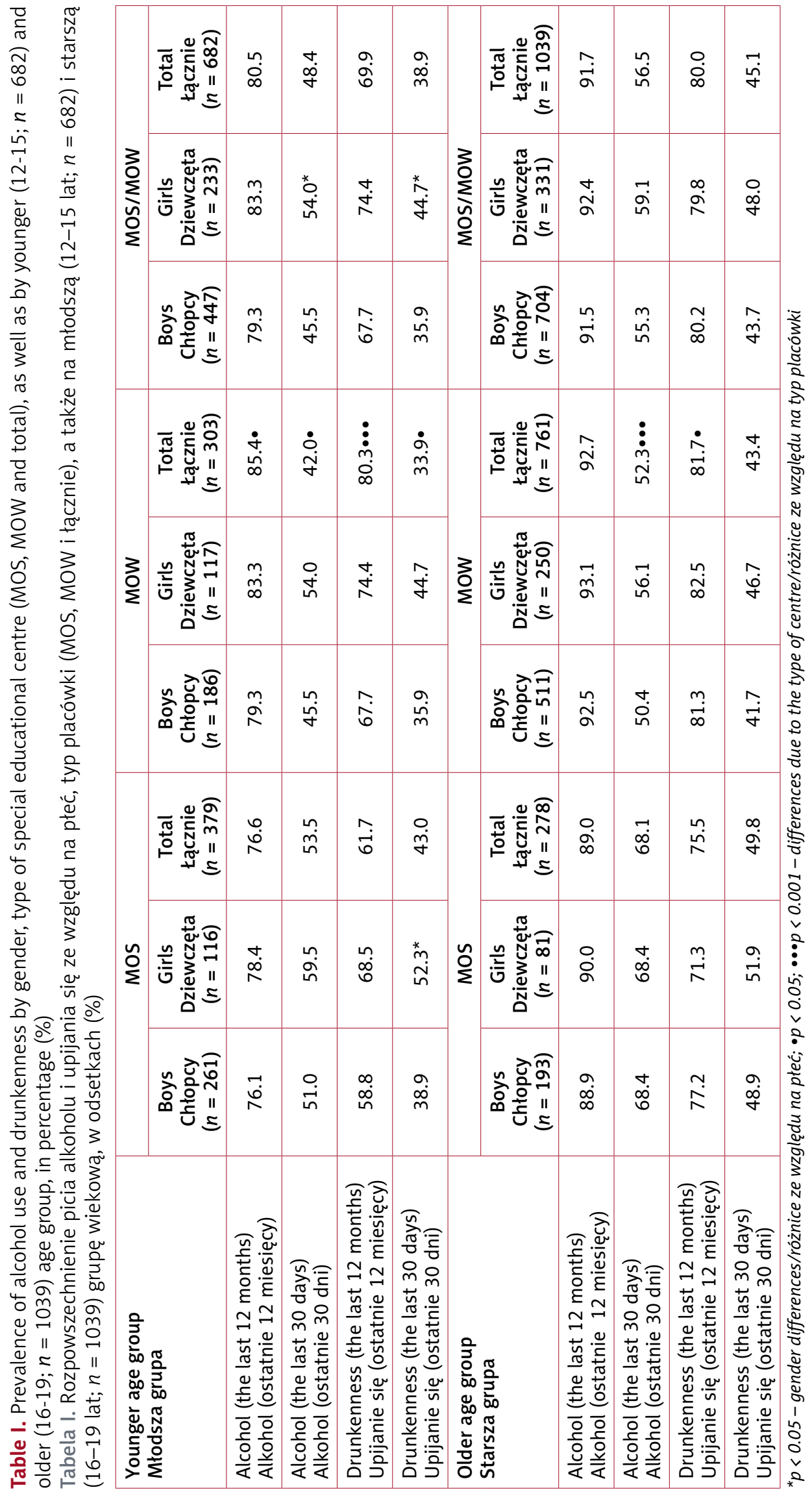


the prevalence of alcohol use and getting drunk in the last 30 days prior to the study was significantly higher in the group of girls than boys $(p<0.05)$. However, these differences (except for drunkenness in the last year in the younger group) were not found when comparing girls and boys attending the same type of centre. Comparison of results by type of centre showed that the prevalence of alcohol use and getting drunk in the last month was significantly higher among MOS students in the younger group $(p<0.05)$. Similary drinking alcohol was higher in the older group $(p<0.001)$. On the other hand, in the last year perspective the percentage of alcohol use $(p<0.05)$ and drunkenness $(p<0.001)$ in the younger group, as well as drunkenness $(p<0.05)$ in the older group were significantly higher among students attending MOW.

\section{The tobacco and e-cigarettes use}

Almost $80 \%$ of the younger and around $87 \%$ of the older respondents from MOS and MOW confirmed that in the last year prior to the survey, they had smoked tobacco in the form of traditional cigarettes, of whom almost $60 \%$ of the younger and over $70 \%$ of the older smoked daily (Table II). These percentages, in both age groups, were higher for students from MOW, especially in case of daily smoking $(p<0.001)$. In turn, gender did not differentiate the smoking prevalence.

E-cigarettes are not so prevalent. Their use in the last year prior to the survey was reported by $55 \%$ of younger and about $44 \%$ of older MOS and MOW students. However, in both these age groups, the percentage of everyday users of e-cigarettes, approximately $11 \%$ in the younger and approximately $9 \%$ in the older age group, was nearly five times lower at both types of centres. In the younger group, the percentage of e-cigarette users was significantly higher among students from MOS $(p<0.01)$. No significant gender differences were noted. Similarly, in the older group, significantly higher percentages of e-cigarette use were noted among adolescents attending MOS in comparison tothan MOW $(p<0.01)$, and among boys than in comparison to girls $(p<0.05)$. w grupie starszej młodzieży z MOS i MOW, przy czym rozpowszechnienie picia alkoholu oraz upijania się w ciągu ostatnich 30 dni przed badaniem było istotnie wyższe $\mathrm{w}$ grupie dziewcząt niż chłopców $(p<0,05)$. Różnic tych ( $\mathrm{z}$ wyjątkiem upijania się w ostatnim roku w grupie młodszej) nie stwierdzono jednak przy porównaniu dziewcząt i chłopców uczęszczających do placówek tego samego typu. Z kolei porównanie wyników ze względu na typ placówki wykazało, że rozpowszechnienie picia alkoholu i upijania się w ciągu ostatniego miesiąca przed badaniem było istotnie większe wśród młodzieży z MOS w grupie młodszej $(p<0,05)$. Wyższe było również rozpowszechnienie picia alkoholu w grupie starszej $(\mathrm{p}<0,001)$. Natomiast w skali ostatniego roku odsetki picia alkoholu $(p<0,05)$ i upijania się $(p<0,001)$ w grupie młodszej, a także upijania się $(p<0,05) \mathrm{w}$ grupie starszej były istotnie wyższe wśród podopiecznych MOW.

\section{Palenie tytoniu i używanie e-papierosów}

Prawie $80 \%$ młodszych i ok. $87 \%$ starszych respondentów z MOS i MOW potwierdziło, że $\mathrm{w}$ ciągu ostatniego roku przed badaniem paliło tytoń $\mathrm{w}$ postaci papierosów tradycyjnych, $\mathrm{z}$ czego prawie $60 \%$ spośród młodszych i ponad $70 \%$ spośród starszych pali je codziennie (tab. II). Odsetki te, w obydwu grupach wiekowych, były wyższe w przypadku podopiecznych MOW niż MOS, szczególnie $\mathrm{w}$ przypadku codziennego palenia $(p<0,001)$. Z kolei płeć nie różnicowała wyników dotyczących palenia papierosów.

E-papierosy nie są tak rozpowszechnione. Ich używanie w ciągu ostatniego roku przed badaniem raportowało 55\% młodszych i ok. 44\% starszych podopiecznych MOS i MOW. W obydwu tych grupach wiekowych obserwuje się jednak prawie pięciokrotnie mniejszy odsetek codziennych użytkowników e-papierosów - ok. 11\% w młodszej i ok. 9\% w starszej grupie wiekowej z obydwu typów placówek. W grupie młodszej odsetki użytkowników e-papierosów były istotnie wyższe wśród podopiecznych MOS niż MOW $(p<0,01)$. Nie odnotowano jednak żadnych istotnych różnic ze względu na płeć. Podobnie $\mathrm{w}$ grupie starszej istotnie wyższe odsetki używania e-papierosów odnotowano wśród młodzieży z MOS w porównaniu $\mathrm{z}$ młodzieżą z MOW $(p<0,01)$ oraz wśród chłopców $\mathrm{w}$ porównaniu $\mathrm{z}$ dziewczętami $(p<0,05)$. 


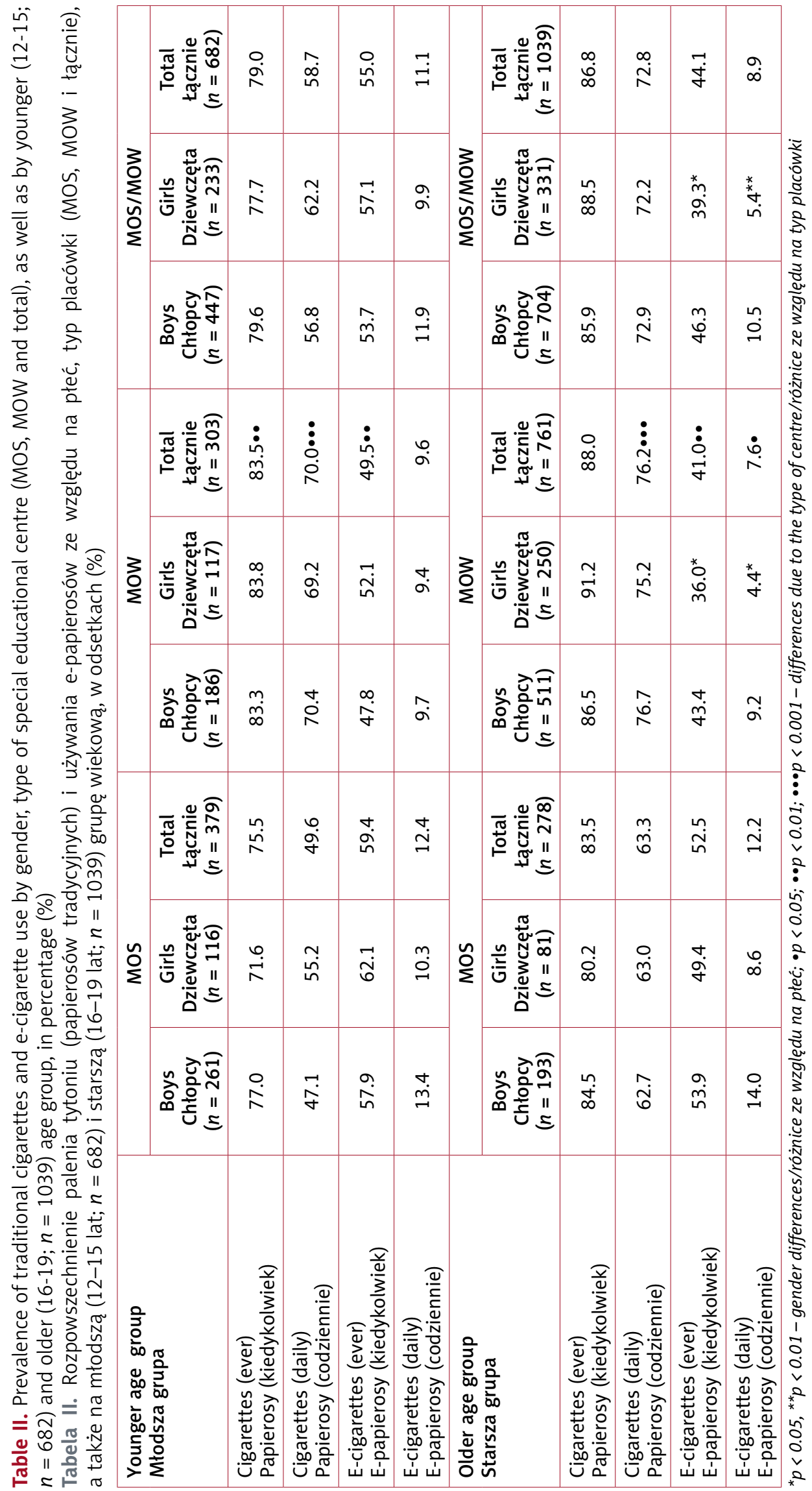


Use of other psychoactive substances

About $64 \%$ of students from MOS and MOW in the younger and $75 \%$ in the older age group had used illegal drugs (the overall rate) in the last 12 months prior to the survey (Table III). The prevalence of these substance use was higher at the MOW (in both age groups) $(p<0.001)$. In addition, these percentages were significantly higher among girls than among boys $(p<0.05)$ though only in the younger age group.

Results regarding the prevalence of the use of particular illegal drugs (Table III) indicate that in the last year cannabis and/or hashish were most commonly used (about $61 \%$ in the younger and about $73 \%$ in the older group). Moreover, the high prevalence of cannabis use has also been observed for the indicator of frequent use, i.e. in the last 30 days prior to the survey (about $38 \%$ in the younger and aboute $43 \%$ in the older age group). The next most frequently indicated substance was amphetamine (about $31 \%$ in the younger group and about $46 \%$ in the older), and then mephedrone (about $26 \%$ in the younger group and over $36 \%$ in the older). A relatively high percentage was also found for the use of psychotropic pharmeceuticals, ecstasy/MDMA, cocaine, hallucinogens and NPS. In the case of the latter, the prevalence of of these substances in the last 30 days prior to the survey was found to be at a relatively high level $(13.5 \%)$ in both age groups. The percentages of use of other substances (codeine, GHB/GBL, heroin/"compote", inhalants, anabolic steroids) ranged from about $2 \%$ to about $9 \%$.

Both the percentage of respondents confirming the use of the most prevalent substances (cannabis, amphetamine, NPS, mephedrone, cocaine and ecstasy/MDMA) as well as the overall drug use rate were significantly higher among the those attending MOW (in both age groups). As for gender differences, these occurred most clearly in the younger age group, where both the overall drug use rate and percentage of participants using such substances like amphetamines, mephedrone, cocaine, NPS, codeine, inhalants and pharmeceuticals were higher for girls than boys. In the older age group, the only significant gender differences were noted in the case of pharmeceuticals, that were used more often by girls, and in the case of steroids, the use of which was more frequent among boys (Table III).
Używanie innych substancji psychoaktywnych

Po narkotyki (wskaźnik ogólny) w ciągu ostatnich 12 miesięcy przed badaniem sięgało ok. 64\% respondentów w młodszej i 75\% w starszej grupie wiekowej z MOS i MOW (tab. III), przy czym rozpowszechnienie tych substancji (w obydwu grupach wiekowych) było wyższe wśród podopiecznych MOW niż MOS $(p<0,001)$. Ponadto odsetki te były istotnie wyższe wśród dziewcząt niż wśród chłopców $(p<0,05)$, ale tylko w młodszej grupie wiekowej.

Wyniki dotyczące rozpowszechnienia używania poszczególnych substancji psychoaktywnych (tab. III) wskazują, że w ciągu ostatniego roku najczęściej używane były przetwory konopi (ok. $61 \% \mathrm{w}$ młodszej i ok. 73\% w starszej grupie). Co więcej, duże rozpowszechnienie używania konopi zaobserwowano także w przypadku wskaźnika świadczącego o częstym sięganiu po te substancje, tj. w ciągu ostatnich 30 dni przed badaniem (w młodszej grupie wiekowej wyniósł on ok. 38\%, a w starszej ok. 43\%). Kolejną najczęściej wskazywaną substancją była amfetamina (ok. $31 \%$ w młodszej i ok. $46 \%$ w starszej grupie), a na trzecim miejscu znalazł się mefedron (ok. 26\% w młodszej i ponad $36 \%$ w starszej grupie). Stosunkowo wysokie odsetki stwierdzono również w przypadku używania leków, ecstasy/MDMA, kokainy, halucynogenów oraz NSP. W przypadku NSP na stosunkowo wysokim poziomie $(13,5 \%)$, i to $\mathrm{w}$ obydwu grupach wiekowych, kształtowało się też rozpowszechnienie używania tych substancji $\mathrm{w}$ ostatnich 30 dniach przed badaniem. Natomiast odsetki używania pozostałych substancji (kodeina, GHB/GBL heroina/,kompot”, inhalanty, sterydy anaboliczne) wahały się w przedziale od ok. $2 \%$ do ok. $9 \%$.

Zarówno odsetki respondentów potwierdzających używanie najbardziej rozpowszechnionych substancji (przetworów konopi, amfetaminy, NSP, mefedronu, kokainy oraz ecstasy/MDMA), jak i wskaźnik ogólny używania narkotyków były istotnie wyższe wśród podopiecznych MOW niż MOS (w obydwu grupach wiekowych). W odniesieniu do różnic ze względu na płeć występują one wyraźnie w młodszej grupie wiekowej, gdzie zarówno wskaźnik ogólny używania narkotyków, jak i odsetki uczestników sięgających po takie substancje, jak amfetaminy, mefedron, kokaina, NSP, kodeina, inhalanty oraz leki, były wyższe w przypadku dziewcząt niż chłopców. Z kolei w starszej grupie wiekowej jedyne istotne różnice ze względu na płeć odnotowano w przypadku leków, po które częściej sięgały dziewczęta, i w przypadku sterydów, których stosowanie było częstsze wśród chłopców (tab. III). 


\begin{tabular}{|c|c|c|c|c|c|c|c|c|c|c|c|c|c|c|c|c|}
\hline 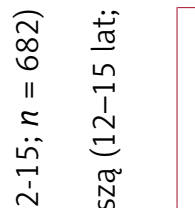 & 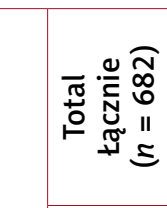 & & $\stackrel{n}{\tilde{n}}$ & $\frac{m}{\vec{b}}$ & $\stackrel{+}{\sim}$ & $\overrightarrow{\vec{m}}$ & 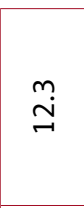 & $\stackrel{\stackrel{f}{\sim}}{\sim}$ & 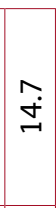 & $\stackrel{9}{\sim}$ & $\stackrel{\infty}{\sigma}$ & 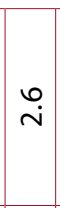 & $\stackrel{m}{+}$ & $\stackrel{+}{*}$ & $\begin{array}{l}n_{\infty}^{n} \\
\stackrel{\infty}{\sim}\end{array}$ & $\stackrel{m}{i}$ \\
\hline 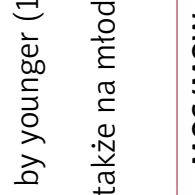 & 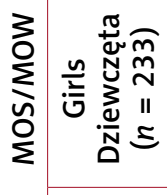 & & $\begin{array}{l}\stackrel{*}{*} \\
\infty \\
0\end{array}$ & $\ddot{8}$ & 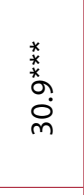 & 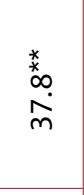 & 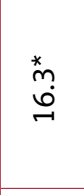 & 走 & $\begin{array}{c}n \\
\underline{\omega} \\
-1\end{array}$ & $\stackrel{*}{\underset{G}{ت}}$ & 伿 & $\stackrel{m}{\rightarrow}$ & $\stackrel{\circ}{\circ}$ & 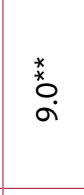 & $\begin{array}{l}x^{*} \\
\infty \\
\infty \\
\infty \\
\stackrel{\infty}{N}\end{array}$ & $\hat{-}$ \\
\hline 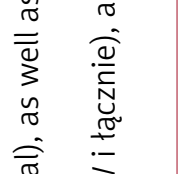 & 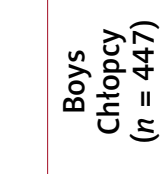 & & @̊ & $\hat{\vec{b}}$ & $\underset{\infty}{\vec{\infty}}$ & $\stackrel{n}{\stackrel{n}{\sim}}$ & $\begin{array}{l}m \\
\stackrel{0}{0}\end{array}$ & $\stackrel{m}{\vec{N}}$ & 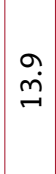 & $\stackrel{m}{\sigma}$ & $\stackrel{+}{\sigma}$ & $\stackrel{\dot{m}}{\dot{m}}$ & $\stackrel{\dot{m}}{m}$ & $\stackrel{b}{\dot{m}}$ & 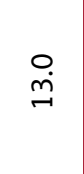 & $\hat{i}$ \\
\hline 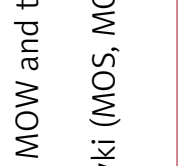 & 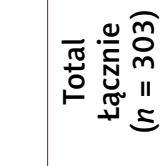 & & $\begin{array}{l}\vdots \\
\dot{0} \\
\stackrel{+}{N}\end{array}$ & $\begin{array}{l}\vdots \\
\stackrel{a}{r} \\
\end{array}$ & $\begin{array}{l}\vdots \\
\stackrel{i}{m} \\
\dot{m}\end{array}$ & $\begin{array}{l}\dot{\leftrightarrow} \\
\stackrel{\leftrightarrow}{+}\end{array}$ & $\begin{array}{l}\vdots \\
\dot{a} \\
\stackrel{-}{-}\end{array}$ & $\begin{array}{l}\vdots \\
\dot{0} \\
\dot{m} \\
m\end{array}$ & $\begin{array}{l}\dot{\vdots} \\
\stackrel{n}{2} \\
\end{array}$ & $\stackrel{0}{\circ}$ & $\begin{array}{l}0 \\
- \\
-\end{array}$ & $\stackrel{\circ}{\stackrel{\sim}{*}}$ & $\dot{\ddot{\theta}}$ & $\stackrel{m}{\sim}$ & $\overrightarrow{\vec{N}}$ & $\dot{\dot{m}}$ \\
\hline 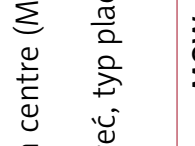 & 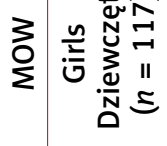 & & ผै & ఏ̊̀ & $\begin{array}{l}\infty \\
\dot{m} \\
\dot{m}\end{array}$ & $\begin{array}{l}b \\
\stackrel{\sigma}{\sigma}\end{array}$ & $\vec{\sim}$ & ח̊. & $\hat{a}$ & $\ddot{\text { in }}$ & $\vec{\exists}$ & $\begin{array}{l}* \\
0 \\
0 \\
0\end{array}$ & $\begin{array}{l}\infty^{\infty} \\
\text {. }\end{array}$ & $\stackrel{*}{\stackrel{*}{\rightleftarrows}} \underset{-}{-}$ & $\begin{array}{l}\text { ڤa } \\
\text { ळે }\end{array}$ & $\stackrel{\Im}{-}$ \\
\hline 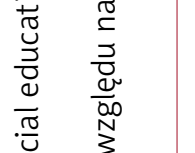 & 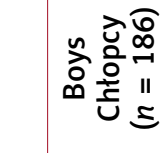 & & $\stackrel{\sim}{\mathbb{N}}$ & $\begin{array}{l}\infty \\
\stackrel{\infty}{n}\end{array}$ & $\stackrel{\substack{\infty \\
\infty}}{\sim}$ & $\stackrel{n}{\stackrel{f}{\sim}}$ & $\hat{0}$ & $\begin{array}{l}\stackrel{a}{\dot{m}} \\
\dot{m}\end{array}$ & ণे & $\stackrel{n}{\sim}$ & $\stackrel{\infty}{\underset{-}{-}}$ & $\stackrel{\leftrightarrow}{\circ}$ & ભ̊̀ & $\begin{array}{l}\infty \\
+\end{array}$ & 尚 & $\stackrel{\infty}{+}$ \\
\hline 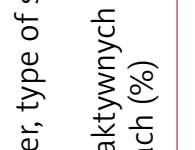 & 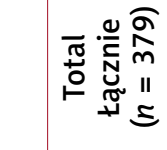 & & $\begin{array}{l}0 \\
\dot{+}\end{array}$ & $\begin{array}{c}n \\
\text { in } \\
n\end{array}$ & $\begin{array}{l}\stackrel{0}{\leftrightarrow} \\
\stackrel{\leftrightarrow}{\rightarrow}\end{array}$ & $\stackrel{\infty}{\stackrel{\infty}{\sigma}}$ & প̆. & 它 & $\begin{array}{l}\infty \\
0 \\
0 \\
-1\end{array}$ & $\stackrel{\circ}{\circ}$ & $\underset{\infty}{+}$ & $\begin{array}{l}0 \\
\rightarrow\end{array}$ & $\stackrel{\leftrightarrow}{\sim}$ & $\stackrel{\circ}{+}$ & 0 & $\stackrel{m}{-}$ \\
\hline 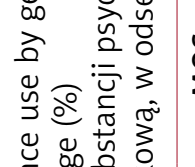 & 足 & & స్ & नேं & $\begin{array}{l}\text { * } \\
\stackrel{*}{\circ} \\
\stackrel{1}{N}\end{array}$ & 苂 & $\stackrel{n}{a}$ & 豙 & $\stackrel{9}{i}$ & 年 & $\begin{array}{l}m \\
\stackrel{-}{0}\end{array}$ & $\stackrel{\Im}{i}$ & $\stackrel{\text { }}{\stackrel{*}{\sim}}$ & જુ & 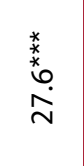 & $\stackrel{-}{-}$ \\
\hline 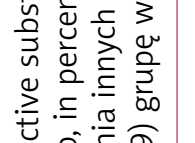 & 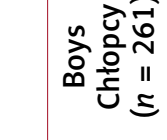 & & $\underset{i n}{m}$ & $\hat{\text { in }}$ & $\hat{\circ}$ & 吕 & $\hat{\text { in }}$ & 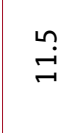 & 号 & $\stackrel{+}{\text { ri }}$ & $\stackrel{\curvearrowright}{\curvearrowright}$ & $\stackrel{\stackrel{n}{\sim}}{\rightarrow}$ & $\stackrel{n}{\rightarrow}$ & $\hat{i}$ & $\vec{ت}$ & $\vec{r}$ \\
\hline 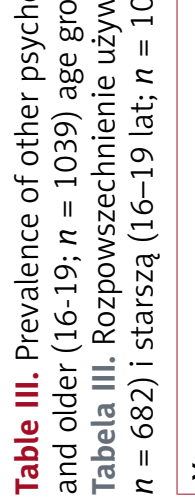 & 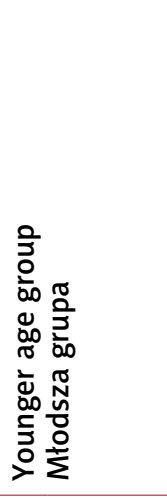 & 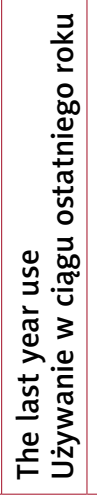 & 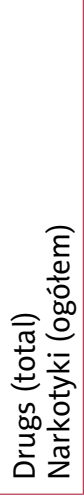 & 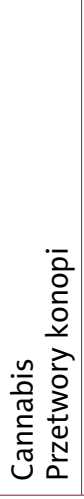 & $\frac{n}{z} \bar{z}$ & 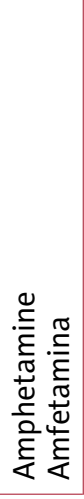 & 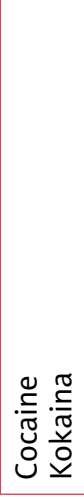 & 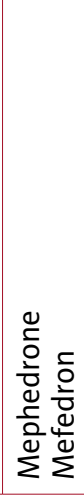 & 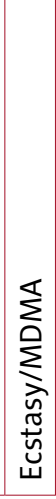 & 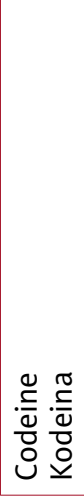 & 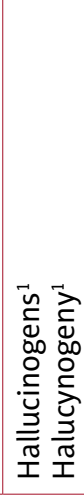 & 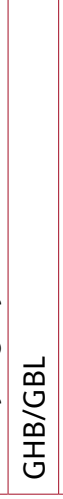 & 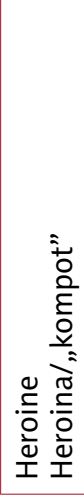 & 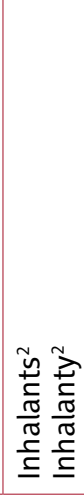 & 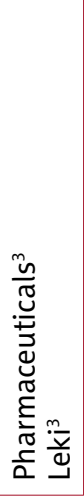 & 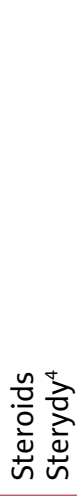 \\
\hline
\end{tabular}




\begin{tabular}{|c|c|c|c|c|c|c|c|c|c|c|c|c|c|c|c|c|c|c|c|}
\hline \multirow{3}{*}{ 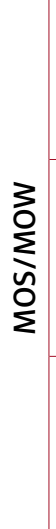 } & 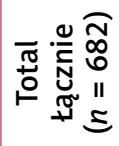 & & $\vec{\infty}$ & $\stackrel{n}{m}$ & & 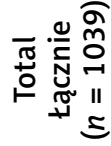 & & $\stackrel{0}{\text { ni }}$ & $\stackrel{\vec{n}}{\sim}$ & $\stackrel{\infty}{\stackrel{\infty}{\sim}}$ & $\begin{array}{l}n \\
\dot{\varphi} \\
\dot{q}\end{array}$ & $\stackrel{\hat{\beth}}{-}$ & $\begin{array}{c}m \\
\dot{m} \\
m\end{array}$ & $\begin{array}{c}0 \\
\infty \\
\sim \\
\sim\end{array}$ & 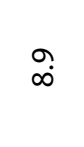 & 亗 & 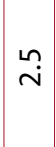 & $\stackrel{m}{\sim}$ & 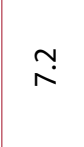 \\
\hline & 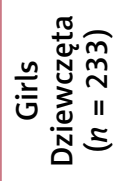 & & $\vec{\circ}$ & 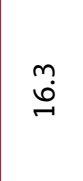 & $\sum_{\substack{0 \\
\Sigma}}^{3}$ & 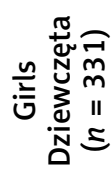 & & $\begin{array}{l}\text { भे } \\
\stackrel{\Gamma}{N}\end{array}$ & $\hat{i}$ & $\stackrel{\circ}{\dot{\varphi}}$ & $\begin{array}{l}\stackrel{\leftrightarrow}{\infty} \\
\infty \\
+\end{array}$ & $\stackrel{n}{\stackrel{n}{ユ}}$ & $\stackrel{\infty}{\stackrel{\infty}{m}}$ & $\stackrel{\mathfrak{s}}{\stackrel{\sim}{\sim}}$ & $\begin{array}{l}\infty \\
\infty \\
\infty\end{array}$ & $\begin{array}{l}\dot{0} \\
\dot{\theta}\end{array}$ & $\stackrel{\stackrel{n}{n}}{\rightarrow}$ & $\stackrel{\sim}{\sim}$ & $\stackrel{\circ}{0}$ \\
\hline & 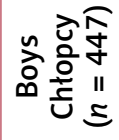 & & $\stackrel{\infty}{\stackrel{\infty}{m}}$ & $\underset{\underset{\sim}{\sim}}{\vec{I}}$ & & 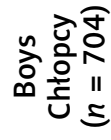 & & $\begin{array}{l}\stackrel{\sigma}{N} \\
\stackrel{N}{n}\end{array}$ & $\stackrel{0}{\stackrel{0}{N}}$ & $\stackrel{\bullet}{\stackrel{0}{N}}$ & $\stackrel{m}{\stackrel{m}{f}}$ & $\stackrel{9}{\underset{丶}{-}}$ & $\stackrel{n}{\stackrel{n}{n}}$ & $\begin{array}{c}m \\
\infty \\
\sim\end{array}$ & $\stackrel{\circ}{\infty}$ & $\stackrel{m}{n}$ & $\stackrel{\circ}{\dot{m}}$ & $\stackrel{+}{+}$ & $\stackrel{\infty}{\wedge}$ \\
\hline \multirow{3}{*}{$\frac{3}{\grave{z}}$} & 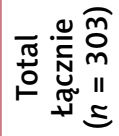 & & $\underset{\stackrel{\sim}{\sim}}{\dot{f}}$ & 离 & & 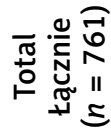 & & $\begin{array}{l}\vdots \\
\substack{\infty \\
i} \\
\end{array}$ & $\begin{array}{l}\vdots \\
\dot{m} \\
\stackrel{0}{n}\end{array}$ & 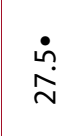 & $\begin{array}{l}\vdots \\
\dot{n} \\
\dot{n}\end{array}$ & $\underset{\sigma}{\dot{\sigma}}$ & $\begin{array}{l}\dot{\vdots} \\
\dot{\circ} \\
\dot{q}\end{array}$ & $\begin{array}{l}\dot{\vdots} \\
\dot{0} \\
\dot{m}\end{array}$ & $\stackrel{0}{\sigma}$ & $\stackrel{\dot{\vec{㇒}}}{\stackrel{-}{二}}$ & $\stackrel{\sim}{\sim}$ & $\stackrel{\curlyvee}{\sim}$ & $\stackrel{\dot{m}}{\infty}$ \\
\hline & 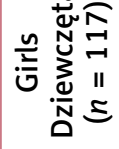 & & $\begin{array}{l}\stackrel{+}{+} \\
\dot{J}\end{array}$ & 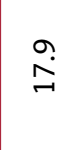 & ${ }^{3}$ & 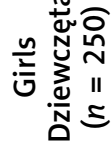 & & $\stackrel{\stackrel{2}{\wedge}}{\wedge}$ & $\begin{array}{l}\text { * } \\
\stackrel{*}{0} \\
\stackrel{0}{0}\end{array}$ & ָั & $\begin{array}{l}\infty \\
\stackrel{\infty}{\circ} \\
\stackrel{0}{n}\end{array}$ & $\stackrel{\sigma}{\circ}$ & $\stackrel{\sim}{m}$ & $\begin{array}{l}0 \\
\dot{D}\end{array}$ & $\stackrel{\circ}{\circ}$ & $\stackrel{+}{\infty}$ & $\stackrel{\sim}{\rightarrow}$ & $\stackrel{\infty}{+}$ & $\stackrel{N}{N}$ \\
\hline & 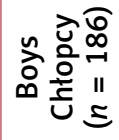 & & @̊̀ & $\stackrel{\llcorner}{\stackrel{+}{+}}$ & & 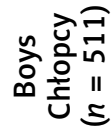 & & $\stackrel{\widehat{\infty}}{\infty}$ & นn & $\begin{array}{l}\dot{0} \\
\stackrel{\dot{\omega}}{N}\end{array}$ & $\stackrel{m}{i}$ & $\stackrel{+}{\circ}$ & ஸे & $\stackrel{\stackrel{n}{n}}{\dot{m}}$ & $\stackrel{\circ}{\circ}$ & 它 & $\vec{m}$ & $\dot{f}$ & $\begin{array}{l}\infty \\
\infty \\
\infty\end{array}$ \\
\hline \multirow{3}{*}{ 气ू } & 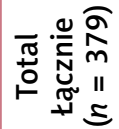 & & $\begin{array}{l}\stackrel{\infty}{\dot{m}} \\
\dot{m}\end{array}$ & $\stackrel{\sigma}{\stackrel{\sigma}{-}}$ & & 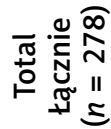 & & ָֻ & 守 & $\stackrel{\sim}{\sim}$ & $\stackrel{+}{\infty}$ & 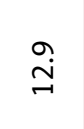 & $\overrightarrow{+}$ & $\overrightarrow{0}$ & 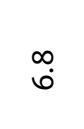 & $\stackrel{\text { g }}{\rightarrow}$ & 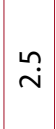 & $\stackrel{\sim}{m}$ & $\stackrel{m}{+}$ \\
\hline & 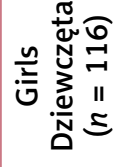 & & $\begin{array}{l}\stackrel{0}{m} \\
m \\
m\end{array}$ & $\stackrel{\Im}{\dot{\Xi}}$ & $\check{\Sigma}_{\Sigma}^{\tilde{\Sigma}}$ & 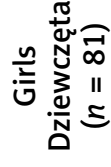 & & $\frac{9}{\hat{\sigma}}$ & นn & ○्. & $\stackrel{\sim}{\sim}$ & $\underset{ت}{ت}$ & $\stackrel{\circ}{\stackrel{i}{N}}$ & $\begin{array}{l}\infty \\
\stackrel{0}{-1}\end{array}$ & ָָ & $\stackrel{ت}{ت}$ & 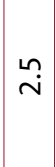 & $\stackrel{\sim}{\sim}$ & $\stackrel{\operatorname{Ln}}{\sim}$ \\
\hline & 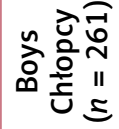 & & 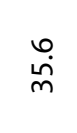 & $\stackrel{n}{\circ}$ & & 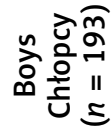 & & $\begin{array}{l}\infty \\
\stackrel{+}{0}\end{array}$ & $\begin{array}{c}m \\
\text { Ln }\end{array}$ & $\stackrel{\infty}{\underset{N}{N}}$ & $\stackrel{\text { กิ }}{\text { กิ }}$ & $\stackrel{\circ}{\dot{\Xi}}$ & 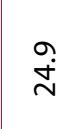 & $\hat{\sigma}$ & $\stackrel{m}{r}$ & $\stackrel{\stackrel{\leftrightarrow}{\sim}}{\sim}$ & $\stackrel{o}{i}$ & $\stackrel{\circ}{\dot{m}}$ & ָָ' \\
\hline \multicolumn{2}{|c|}{ 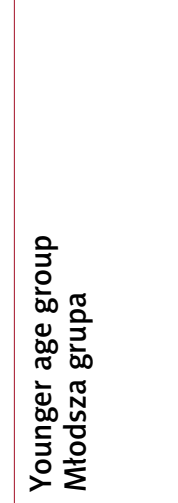 } & 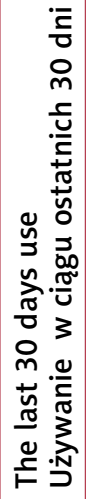 & 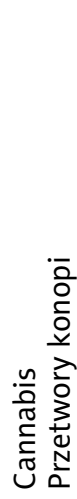 & $\frac{n}{z} \bar{n} z$ & \multicolumn{2}{|c|}{ 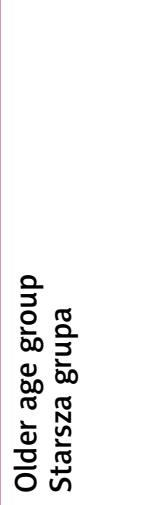 } & 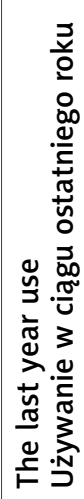 & 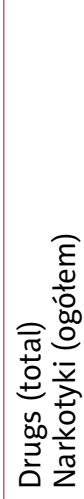 & 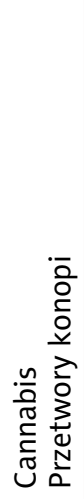 & $\frac{n}{z} \bar{n}$ & 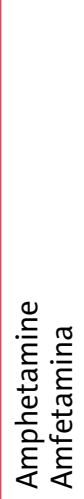 & 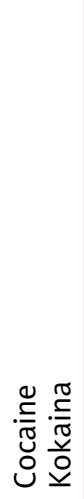 & 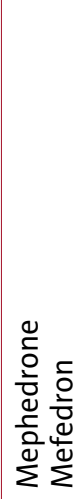 & 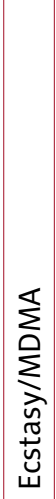 & 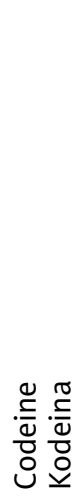 & 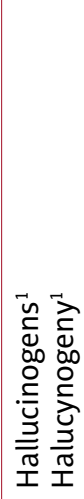 & 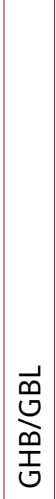 & 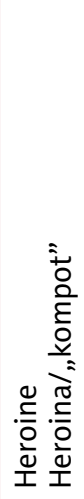 & 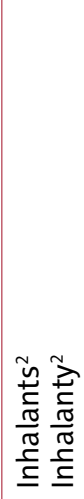 \\
\hline
\end{tabular}




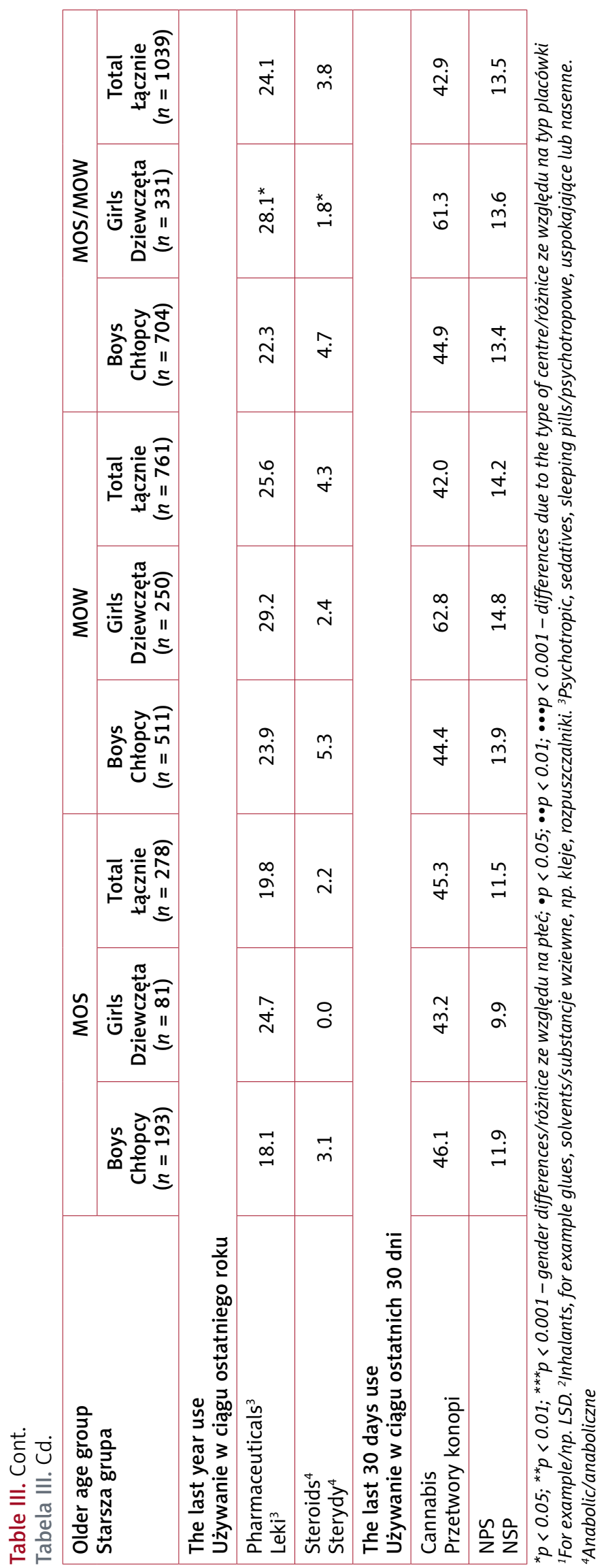


Results from MOS/MOW in the context of the general population of young people in Poland

\section{Younger group}

According to expectations, the comparison of results from our study with data on the prevalence of the use of various psychoactive substances among 15-year-olds attending regular schools (ESPAD study) indicates definitely higher prevalence among MOS and MOW students (Figure 1). The exceptions are two indicators in the subgroup of boys (alcohol use in the last 30 days and the use of inhalants in the last year prior to study), the prevalence of which was several percentage points higher
Wyniki uzyskane w MOS/MOW na tle ogólnej populacji polskiej młodzieży

\section{Grupa młodsza}

Zgodnie z oczekiwaniami zestawienie wyników naszych badań z danymi dotyczącymi rozpowszechnienia używania różnych substancji psychoaktywnych wśród 15-latków uczących się w szkołach ogólnodostępnych (badania ESPAD) wskazuje, że rozpowszechnienie to jest zdecydowanie wyższe wśród młodzieży z MOS i MOW (ryc. 1). Wyjątkami są jednak dwa wskaźniki w podgrupie chłopców (picie alkoholu w ciągu ostatnich 30 dni i używanie inhalantów w ciągu ostatniego roku), których rozpowszechnienie było większe o kilka punktów procentowych wśród chłopców ze szkół ogólnodostępnych.
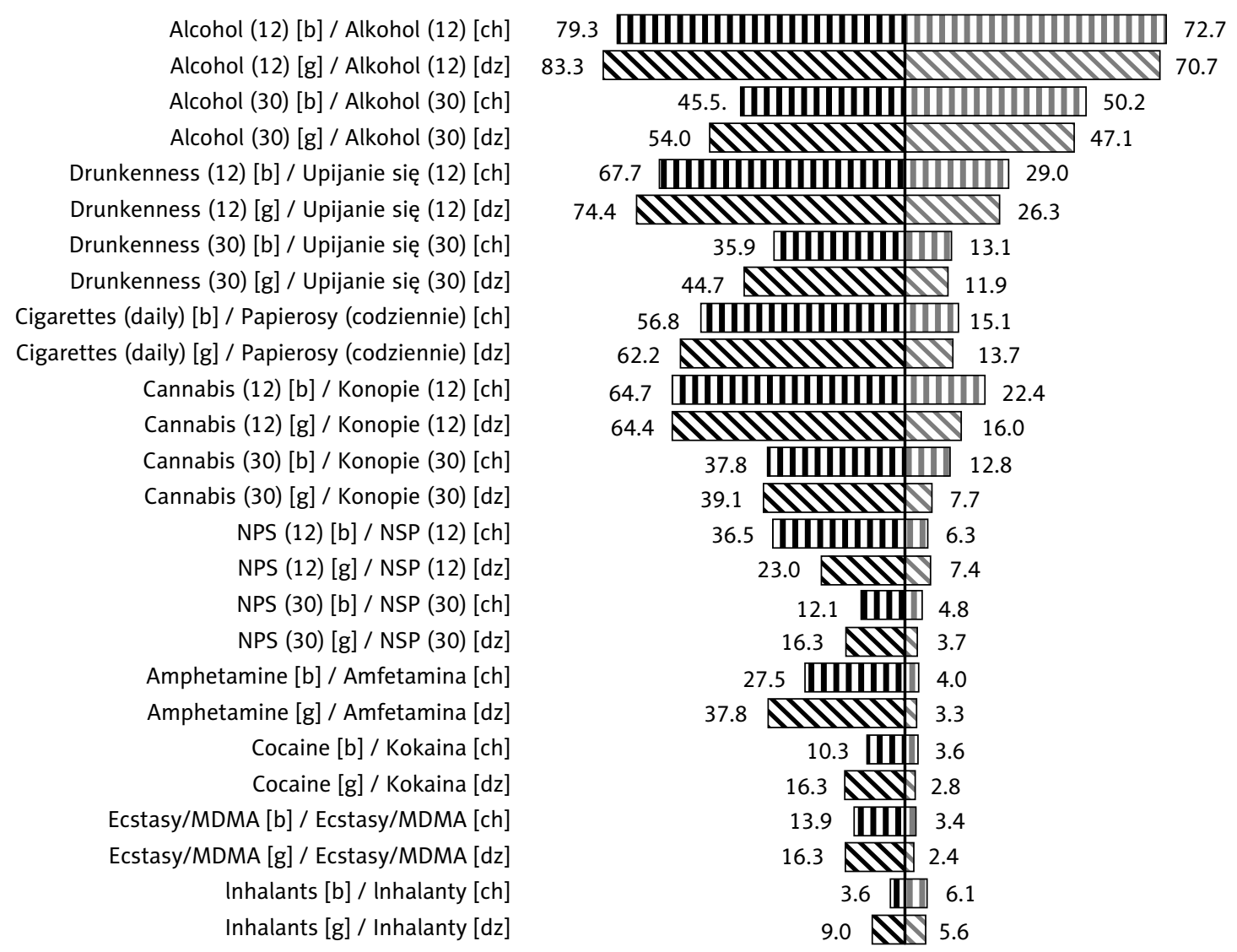

Figure 1. Summary of the prevalence of various psychoactive substance use among students of the Polish special education centres (results on the left) against the results of the general population of Polish adolescents from the ESPAD study (results on the right), divided by gender ([b] - boys, vertical lines; [g] - girls, diagonal lines) and the time frame ("12" or without a signature - last 12 months; "30" - last 30 days) - younger group

Rycina 1. Zestawienie rozpowszechnienia używania różnych substancji psychoaktywnych wśród podopiecznych MOS/MOW (wyniki po lewej) na tle wyników ogólnej populacji polskiej młodzieży z badań ESPAD (wyniki po prawej), z podziałem na płeć ([ch] - chłopcy, linie pionowe; [dz] - dziewczęta, linie ukośne) oraz przedział czasu („12” lub bez oznaczenia - w ciągu ostatnich 12 miesięcy; „30” - w ciągu ostatnich 30 dni) - grupa młodsza 
among boys from regular school. The smallest differences in results between students from MOS/MOW and regular schools have been reported for alcohol use. However, these differences increase significantly when taking into account the rates of drunkenness (twice as high among MOS/MOW students). The difference is also very clear in case of daily smoking (up to four times higher among MOS/MOW students). The prevalence of illegal drug use among students attending MOS/MOW is also much higher than in case of regular schools. For example, in the last year prior to the survey, cannabis use was three times more common among boys and four times more common among girls, NPS use was three times more common among girls and
Najmniejsze różnice wyników pomiędzy wychowankami MOS/MOW a uczniami szkół ogólnodostępnych odnotowano w przypadku picia alkoholu. Różnice te zwiększają się jednak znacząco, jeśli weźmie się pod uwagę wskaźniki upijania się (ponad podwukrotnie większe w przypadku młodzieży z MOS/MOW). Bardzo wyraźna jest także różnica w codziennym paleniu papierosów (nawet czterokrotnie wyższe odsetki w przypadku młodzieży z MOS/MOW). Dużo wyższe jest także rozpowszechnienie używania narkotyków wśród podopiecznych MOS/MOW w zestawieniu $\mathrm{z}$ rozpowszechnieniem używania tych substancji w szkołach ogólnodostępnych. Na przykład w ciągu ostatniego roku przed badaniem używanie przetworów konopi było trzy razy częstsze wśród chłopców i cztery razy częstsze wśród dziewcząt, używanie NSP

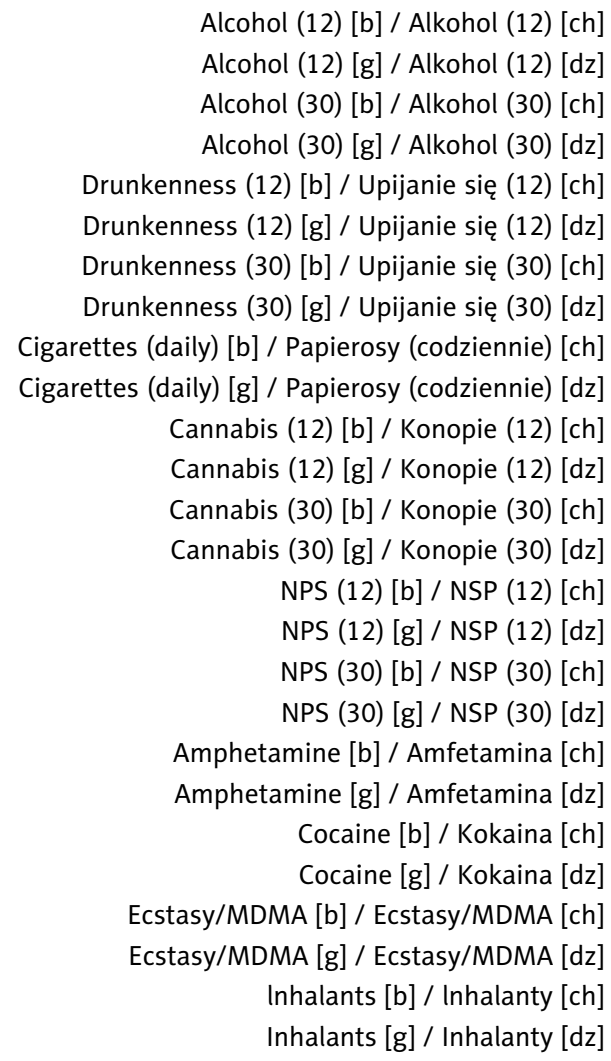

Alcohol (12) [b] / Alkohol (12) [ch] (12) [dz] Alcohol (30) [b] / Alkohol (30) [ch] Drunkenness (12) [b] / Upijanie się (12) [ch] Drunkenness (12) [g] / Upijanie się (12) [dz] Drunkenness (30) [b] / Upijanie się (30) [ch] Drunkenness (30) [g] / Upijanie się (30) [dz] Cigarettes (daily) [b] / Papierosy (codziennie) [ch] Cannabis (12) [b] Cannabis (12) [g] / Konopie (12) [dz] Cannabis (30) [b] / Konopie (30) [ch] Cannabis (30) [g] / Konopie (30) [dz] NPS (12) [b] / NSP (12) [ch] NPS (12) [g] / NSP (12) [dz] PS (30) [b] / NSP (30) [ch] NPS (30) [g] / NSP (30) [dz] Amphetamine [b] / Amfetamina [ch] Cocaine [b] / Kokaina [ch] Cocaine [g] / Kokaina [dz] Ecstasy/MDMA [b] / Ecstasy/MDMA [ch] Inhalants [b] / Inhalanty [ch] Inhalants [g] / Inhalanty [dz]

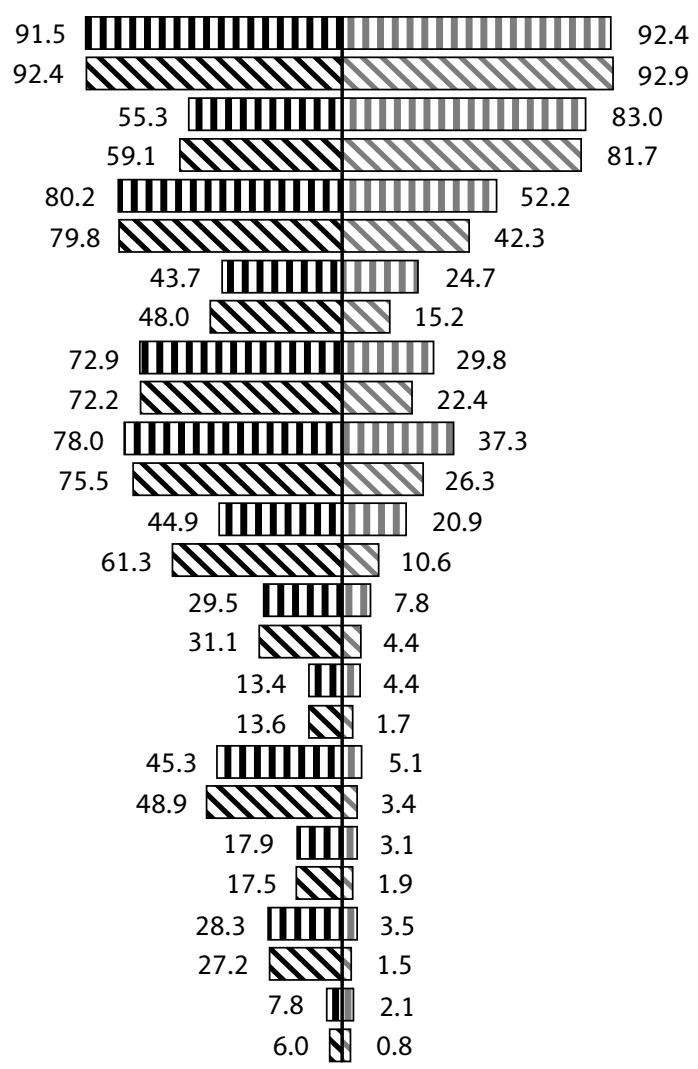

Figure 2. Summary of the prevalence of various psychoactive substance use among students of the Polish special education centres (results on the left) against the results of the general population of Polish adolescents from the ESPAD study (results on the right), divided by gender ([b] - boys, vertical lines; [g] - girls, diagonal lines) and the time frame ("12" or without a signature - last 12 months; "30" - last 30 days) - older group

Rycina 2. Zestawienie rozpowszechnienia używania różnych substancji psychoaktywnych wśród podopiecznych MOS/MOW (wyniki po lewej) na tle wyników ogólnej populacji polskiej młodzieży z badań ESPAD (wyniki po prawej), z podziałem na płeć ([ch] - chłopcy, linie pionowe; [dz] - dziewczęta, linie ukośne) i przedział czasu („12” lub bez oznaczenia - w ciągu ostatnich 12 miesięcy; „30” - w ciągu ostatnich 30 dni) - grupa starsza 
more than six times more common among boys, while amphetamine use was almost seven times more common among boys and up to eleven times more common among MOS/MOW girls compared to the ESPAD study results.

\section{The older group}

Generally, the higher prevalence of the use of various psychoactive substances among older MOS/MOW students compared in the context of the results of the ESPAD study conducted among 17-year-olds are in line with expectations (Figure 2). As with younger groups, the exception is the rate of alcohol consumption in the last 30 days before the study, though this time it includes the girls as well. Drunkenness (both during the last year and last 30 days) was definitely higher among students attending MOS and MOW. In addition, as in the younger group, the percentage of drug use and daily cigarette smoking was clearly higher among students from MOS/MOW than among those from regular schools. For example, the use of cannabis (in the last month) was twice as high among boys and six times higher among girls. However, in the case of other substances the percentages were from a few (NPS, cocaine and inhalants) to up to a dozen times higher (amphetamine and ecstasy/MDMA among girls) among adolescents attending MOS/MOW.

\section{- Discussion}

The aim of this study was to analyse the prevalence and differences in psychoactive substance use among students attending MOS and MOW by gender, age and type of educational centre. In addition, the results obtained were compared with that of studies on the general population of young people in Poland. Our study involved a nationwide sample of socially maladjusted youth and those at risk of social maladjustment, which gave it supplementary status to previous research on the use of psychoactive substances among Polish young people.

The results of our research confirm previous domestic [27] and foreign [5] reports of a very high prevalence of psychoactive substance use among students from educational institutions for young people at risk of social maladjustment. Apart from alcohol use rates, which were at a similar level to było trzy razy częstsze wśród dziewcząt i ponad sześć razy częstsze wśród chłopców, natomiast używanie amfetaminy było prawie siedem razy częstsze wśród chłopców i aż jedenaście razy częstsze wśród dziewcząt z MOS/MOW, w zestawieniu z rozpowszechnieniem używania tych substancji w badaniach ESPAD.

\section{Grupa starsza}

Ogólnie wyższe rozpowszechnienie używania różnych substancji psychoaktywnych wśród starszych podopiecznych MOS/MOW na tle wyników pochodzących $\mathrm{z}$ badań ESPAD prowadzonych wśród 17-latków jest zgodne $\mathrm{z}$ oczekiwaniami (ryc. 2). Podobnie jak w przypadku młodszych grup młodzieży, wyjątkiem jest wskaźnik odnoszący się do picia alkoholu w ciągu ostatnich 30 dni przed badaniem, chociaż tym razem obejmuje to również dziewczęta. Z kolei upijanie się (zarówno w ciągu roku, jak i w ostatnich 30 dniach) było zdecydowanie wyższe wśród podopiecznych MOS i MOW. Ponadto, tak jak w grupie młodszej, odsetki używania narkotyków i codziennego palenia papierosów były wyraźnie wyższe wśród młodzieży z MOS/MOW na tle uczniów szkół ogólnodostępnych. Na przykład używanie przetworów konopi (w ciągu ostatniego miesiąca) wśród chłopców było dwukrotnie, a wśród dziewcząt aż sześciokrotnie wyższe. Natomiast $\mathrm{w}$ przypadku pozostałych substancji odsetki te były od kilku (NSP, kokaina oraz inhalanty) do nawet kilkunastu razy (amfetamina i ecstasy/MDMA wśród dziewcząt) wyższe wśród młodzieży z MOS/MOW.

\section{- OMÓWIENIE}

Celem badania była analiza rozpowszechnienia oraz różnic $\mathrm{w}$ używaniu substancji psychoaktywnych wśród podopiecznych MOS i MOW ze względu na płeć, wiek oraz typ placówki. Dodatkowo otrzymane wyniki zestawiono z wynikami badań ogólnej populacji polskiej młodzieży. Badaniem objęto ogólnokrajową próbę młodzieży społecznie niedostosowanej i zagrożonej niedostosowaniem społecznym, dzięki czemu ma ono charakter uzupełniający w stosunku do dotychczasowych badań nad problematyką używania substancji psychoaktywnych wśród polskiej młodzieży.

Wyniki naszych badań potwierdzają wcześniejsze krajowe [27] i zagraniczne [5] doniesienia o bardzo wysokim rozpowszechnieniu używania substancji psychoaktywnych wśród podopiecznych placówek oświatowych przeznaczonych dla młodzieży zagrożonej niedostosowaniem społecznym. Poza wskaźnikami picia alkoholu, które kształtowa- 
the general population of school youth [2], MOS/ MOW students had a significantly higher prevalence of using the other substances analysed. These results confirm the assumptions about a much higher prevalence of these risky behaviours among young people attending MOS/MOW compared to those in regular schools.

A comparison of the MOS and MOW results indicates that the use of most of the substances was more common among young people from MOW. At the same time, it should be emphasised that in the case of MOW students, all of the indicators of risky patterns of use (drunkenness, daily smoking of traditional cigarettes, using illegal drugs and using NPS) were higher. This is not a surprising result, considering that the use of psychoactive substances, along with offenses and problem behaviours, as well as failure to complete school duties, is one of the most common reasons for referring young people to such facilities [7]. Therefore, it is not surprising that the prevalence of the use of the majority of the psychoactive substances is higher in this group of adolescents, compared to those at MOS, among whom adaptive problems and manifestations of emotional disorders dominate $[7,8]$. Moreover, very high rates of illegal drug use among adolescents from both types of facilities are associated with exposure to strong social risk factors like substance use by peers and adults in the immediate environment [32]. These factors shape attitudes and norms conducive to the use of psychoactive substances, as well as induce and model behaviour of this kind.

An interesting phenomenon was observed in the case of alcohol use and drunkenness rates in the last month prior to the survey. These rates were much higher at MOS, while in the last year the rates of drinking and getting drunk were higher among the young people attending MOW. This phenomenon is probably caused by differences in the functioning of these facilities. Unlike MOW, which provides accommodation for all pupils, in some of the MOS adolescents leave the centre every weekend or even commute daily from their place of residence $[8,33]$. What is more, MOS-type facilities run educational activities throughout the school year, and students enjoy the same school holidays and vacations as regular school students. MOW, on the other ły się na podobnym poziomie jak w populacji generalnej młodzieży szkolnej [2], wśród podopiecznych MOS/MOW zaobserwowano znacznie wyższe rozpowszechnienie używania pozostałych analizowanych substancji. Wyniki te potwierdzają przypuszczenia o znacznie wyższym rozpowszechnieniu tych zachowań ryzykownych wśród młodzieży kierowanej do placówek MOS/MOW w porównaniu z młodzieżą ze szkół ogólnodostępnych.

Natomiast porównanie wyników podopiecznych MOS i MOW wskazuje, że używanie większości z badanych substancji było bardziej rozpowszechnione wśród młodzieży z MOW. Należy podkreślić również, że w przypadku podopiecznych MOW wyższe były wszystkie ze wskaźników świadczących o ryzykownych wzorach używania (upijanie się, codzienne palenie papierosów, używanie substancji nielegalnych i używanie NSP). Nie jest to wynik zaskakujący, biorąc pod uwagę, że używanie substancji psychoaktywnych, obok wykroczeń i zachowań problemowych oraz nierealizowania obowiązków szkolnych, jest jednym z najczęstszych powodów kierowania młodzieży do tego typu placówek [7]. Zrozumiałe jest więc, że rozpowszechnienie używania większości $\mathrm{z}$ badanych substancji jest wyższe $w$ tej grupie młodzieży w porównaniu z podopiecznymi MOS, u których dominują raczej problemy adaptacyjne i przejawy zaburzeń emocjonalnych $[7,8]$. Co więcej, bardzo wysokie wskaźniki używania narkotyków wśród młodzieży z obydwu typów placówek mają związek z ekspozycją na silne społeczne czynniki ryzyka, takie jak używanie substancji przez rówieśników i dorosłych z najbliższego otoczenia [32]. Czynniki te kształtują bowiem postawy i normy sprzyjające używaniu substancji psychoaktywnych, a także indukują i modelują podejmowanie takich zachowań.

Ciekawe zjawisko zaobserwowano w przypadku wskaźników picia alkoholu i upijania się w ostatnim miesiącu przed badaniem. Otóż wskaźniki te były znacznie wyższe wśród podopiecznych MOS, podczas gdy w skali ostatniego roku wskaźniki picia i upijania się były wyższe wśród młodzieży z MOW. Przyczyną tego zjawiska są prawdopodobnie różnice $\mathrm{w}$ funkcjonowaniu tych placówek. W odróżnieniu od MOW, które zapewniają internaty wszystkim podopiecznym, w przypadku niektórych MOS podopieczni opuszczają placówkę w każdy weekend lub nawet docierają na codzienne zajęcia ze swoich miejsc zamieszkania $[8,33]$. Co więcej, placówki typu MOS prowadzą działalność edukacyjną przez cały rok szkolny, a uczniowie korzystają z ferii i wakacji szkolnych jak ucznio- 
hand, operate throughout the entire calendar year, and leave is granted only by district court rulings [33]. MOW facilities have greater control over their students, which significantly limits the availability of alcohol and other psychoactive substances, and thus affects the frequency of taking these substances. Therefore it is understandable that the prevalence of drinking alcohol and getting drunk in the month prior to the survey was higher among MOS students, despite the higher prevalence of these behaviours throughout the year among those from MOW. Furthermore, an analogous phenomenon was observed in the case of contrasting the results of MOS/MOW students with students of regular schools.

Another important observation from our study is the differences in the prevalence of specific psychoactive substance use in terms of gender. Girls attending MOS/MOW centres (especially in the younger age group) were more likely to use such substances like alcohol, stimulants, NPS, codeine or pharmaceuticals. This result is surprising considering the fact that in the group of regular school students, gender differences (except for the percentage of pharmaceuticals) are either insignificant or predominant on the side of boys [2, $11,12]$. More frequent use of these substances by girls attending MOS/MOW is probably associated with a higher risk factor intensity in comparison to boys, making them more prone to behave in a risky manner [34]. This kind of behaviour is usually more common among boys and therefore associated with the male gender. Therefore, it can be supposed that girls at risk of social maladjustment that attend MOS/MOW usually have more complex and serious problems than boys referred to these facilities [19].

\section{Limitations of study}

The limitations of the presented results are related to how data on the frequency of use of individual psychoactive substances had been collected. It is difficult to verify the reliability of the responses when using self-administered survey approach. However, the recommended procedures were used in this study to reduce these difficulties [9]. wie szkół ogólnodostępnych, natomiast MOW prowadzą działalność przez cały rok kalendarzowy, a podopieczni dostają przepustki jedynie za zgodą sądu rejonowego [33]. W porównaniu z MOS placówki MOW cechuje większa kontrola nad swoimi podopiecznymi, co znacznie ogranicza dostępność do alkoholu i innych substancji psychoaktywnych, a tym samym wpływa na częstość sięgania po te substancje. W związku z tym zrozumiałe jest, dlaczego rozpowszechnienie picia alkoholu i upijania się w ostatnim miesiącu przed badaniem jest wyższe wśród podopiecznych MOS, pomimo wyższego rozpowszechnienia tych zachowań w skali całego roku wśród wychowanków MOW. Ponadto analogiczne zjawisko zaobserwowano w przypadku zestawienia wyników podopiecznych MOS/MOW z uczniami szkół ogólnodostępnych.

Kolejną ważną obserwacją z naszych badań są różnice $\mathrm{w}$ rozpowszechnieniu używania poszczególnych substancji psychoaktywnych ze względu na płeć. Mianowicie dziewczęta skierowane do placówek MOS/MOW (szczególnie w młodszej grupie wiekowej) częściej niż chłopcy sięgają po takie substancje jak alkohol, stymulanty, NSP, kodeina czy leki psychotropowe. Wynik ten jest zaskakujący, jeśli wziąć pod uwagę fakt, że w grupie młodzieży ze szkół ogólnodostępnych różnice ze względu na płeć (z wyjątkiem odsetka używania leków) są albo nieistotne, albo $z$ przewagą po stronie chłopców $[2,11$, 12]. Częstsze sięganie po te substancje przez dziewczęta z MOS/MOW jest prawdopodobnie związane z wyższym niż u chłopców nasileniem czynników ryzyka, które sprawiają, że dziewczęta te zachowują się w sposób ryzykowny [34]. Podejmowanie takich zachowań jest bowiem $\mathrm{z}$ reguły częstsze wśród chłopców i przez to kojarzone z płcią męską. W związku z tym można przypuszczać, że zagrożone niedostosowaniem społecznym dziewczęta kierowane do MOS/MOW przejawiają zwykle bardziej złożone i poważne problemy niż kierowani do tych placówek chłopcy [19].

\section{Ograniczenia badań}

Ograniczenia zaprezentowanych tu wyników są związane z zastosowanym sposobem zbierania danych na temat częstości używania poszczególnych substancji psychoaktywnych. Korzystając z metody audytoryjnych badań ankietowych, trudno jest zweryfikować wiarygodność odpowiedzi. W badaniu tym zastosowano jednak procedury rekomendowane w celu ograniczenia tych trudności [9]. 
It is also worth paying attention to the high percentage of respondents confirming the use of substances such as cocaine, amphetamine, hallucinogens and cannabis. It can be assumed that, in the era of the dissemination of NPS, some of the substances obtained by young people under the name of classic drugs could in fact be their synthetic equivalents or contain only a trace of these substances [35]. NPS have appeared on the drug scene, inter alia, due to the illegality of psychoactive substances (classic drugs), in order to replace them as legal and easily accessible substances with similar effects [36]. This may also explain the very high rates of declared use of certain substances (cannabis, amphetamines, cocaine or ecstasy/MDMA), which may actually have been NPS.

The limitations that emerge while comparing our results with the ESPAD study also need to be mentioned. Not all questions to measure the frequency of psychoactive substance use were identical in both studies, which clearly limits the accuracy of our comparisons. The major differences were between the questions about drunkenness. In the case of MOS and MOW facilities, the question was simply: On how many occasions have you been intoxicated from drinking beer, wine or vodka? While in the ESPAD study, students were asked about: $O n$ how many occasions (if any) have you been intoxicated from drinking alcoholic beverages, for example staggered when walking, not being able to speak properly, throwing up or not remembering what happened? [2]. On the one hand, the content of this question could significantly overestimate the frequency of alcohol intoxication among MOS/MOW students due to its subjective nature, whereas on the other, it could have encouraged the understatement of affirmative answers in the ESPAD study due to the adopted criteria.

\section{- CONCLUSiONS}

Due to the very high prevalence of the use of various types of psychoactive substances, which were primarily illegal substances, as well as the results indicating the risky patterns of use, adolescents attending MOS and MOW are at increased risk of experiencing substance-use related
Warto także zwrócić uwagę na wysokie odsetki respondentów potwierdzających używanie takich substancji jak kokaina, amfetamina, halucynogeny czy przetwory konopi. Można przypuszczać, że w dobie rozpowszechnienia NSP i substancji zastępczych na rynku substancji psychoaktywnych część $z$ pozyskanych przez młodzież substancji sprzedawanych pod nazwą klasycznych narkotyków w rzeczywistości mogła być syntetycznymi odpowiednikami lub zawierać jedynie domieszkę tych substancji [35]. NSP pojawiły się na scenie narkotykowej m.in. $\mathrm{z}$ powodu nielegalności substancji psychoaktywnych (narkotyków), mając je zastąpić jako legalne i łatwo dostępne substancje o analogicznym działaniu [36]. Może to również wyjaśniać bardzo wysokie wskaźniki deklarowanego używania niektórych substancji (przetwory konopi, amfetamina, kokaina czy ecstasy/MDMA), które $\mathrm{w}$ rzeczywistości mogły być NSP.

Należy też wymienić ograniczenia dotyczące zestawienia naszych wyników z wynikami badań ESPAD. Nie wszystkie pytania do pomiaru częstości używania substancji psychoaktywnych wykorzystane w obu badaniach były identyczne. To w oczywisty sposób ogranicza dokładność naszych zestawień. Największe różnice występowały pomiędzy pytaniami o upijanie się. W przypadku młodzieży z placówek MOS i MOW pytano po prostu o to: Ile razy zdarzyło Ci się upić piwem, winem lub wódką. Z kolei w badaniu ESPAD pytano o: silne upicie się, tzn. wypicie tyle, żeby np. zataczać się, bełkotać, nie pamiętać co się działo [2]. Treść tego pytania mogła z jednej strony spowodować istotne przeszacowanie częstości intoksykacji alkoholem w grupie młodzieży z MOS/MOW (ze względu na jej subiektywny charakter), a $\mathrm{z}$ drugiej mogła wpływać na zaniżenie twierdzących odpowiedzi wśród młodzieży z badań ESPAD (ze względu na przyjęte kryteria upicia się).

\section{WNIOSKI}

Ze względu na bardzo wysokie rozpowszechnienie używania różnego rodzaju substancji psychoaktywnych, w tym przede wszystkim substancji nielegalnych, a także wyniki świadczące o ryzykownych wzorach używania, młodzież uczęszczająca do placówek MOS i MOW znajduje się w grupie podwyższonego ryzyka doświadczania szkód i problemów związanych z używaniem tych substancji. 
harms and problems. This threat applies especially to girls and students from MOW. The results of this study support and emphasise the need to expand the range of preventive and therapeutic programmes and interventions aimed at preventing and reducing risks and harms associated with psychoactive substance use in these groups of young people. These efforts should not, however, be limited to the problem of psychoactive substance use itself but also include other related problem behaviours that are associated with substance use.

Continued research on the prevalence of psychoactive substance use among MOS and MOW students is necessary to assess trends and the effectiveness of preventive and therapeutic interventions implementation. Furthermore, studies should include measurements that allow a more precise analysis of the prevalence of risky patterns of substance use. An example is the pattern of poly-substance use, the high intensity of which was noted in foreign studies of young people attending educational institution other that regular schools [21].
Zagrożenie to dotyczy szczególnie dziewcząt oraz podopiecznych MOW. Wyniki tego badania potwierdzają i podkreślają potrzebę poszerzenia oferty programów i interwencji profilaktyczno-terapeutycznych ukierunkowanych na zapobieganie oraz ograniczanie ryzyka i szkód związanych z używaniem substancji psychoaktywnych w tych grupach młodzieży. Oddziaływania te nie powinny jednak ograniczać się jedynie do problematyki używania substancji psychoaktywnych, ale także obejmować inne związane $\mathrm{z}$ tym zachowania problemowe.

Kontynuacja badań z zakresu rozpowszechnienia używania substancji psychoaktywnych wśród podopiecznych placówek MOS i MOW jest konieczna dla oszacowania trendów oraz oceny skuteczności stosowanych oddziaływań profilaktycznych i terapeutycznych. Co więcej, w dalszych badaniach należałoby uwzględnić pomiary umożliwiające bardziej precyzyjną analizę rozpowszechnienia ryzykownych wzorów używania substancji. Przykładem jest zjawisko politoksykomanii, którego wysokie nasilenie zostało odnotowane w zagranicznych badaniach młodzieży uczącej się w innych niż ogólnodostępne placówki oświatowe [21].

\section{Conflict of interest/Konflikt interesów}

None declared./Nie występuje.

\section{Financial support/Finansowanie}

The article was prepared within the frame of the research project financed by the National Health Programme for 2016-2020.

Artykuł został przygotowany w ramach projektu badawczego finansowanego ze środków Narodowego Programu Zdrowia na lata 2016-2020.

\section{Ethics/Etyka}

The project "Supporting research in the area of risk and protective factors associated with alcohol-use related problems" was approved by the Bioethics Committee of the Institute of Psychiatry and Neurology in Warsaw, Resolution No. 342017 of 26 October 2017.

Projekt „Wspieranie badań naukowych w obszarze czynników ryzyka i czynników chroniących przed problemami wynikającymi z picia alkoholu" uzyskał zgodę Komisji Bioetycznej Instytutu Psychiatrii i Neurologii w Warszawie, Uchwała nr 342017 z dnia 26 października 2017 r.

The work described in this article has been carried out in accordance with the Code of Ethics of the World Medical Association (Declaration of Helsinki) on medical research involving human subjects, Uniform Requirements for manuscripts submitted to biomedical journals and the ethical principles defined in the Farmington Consensus of 1997.

Treści przedstawione w pracy są zgodne z zasadami Deklaracji Helsińskiej odnoszącymi się do badań $\mathrm{z}$ udziałem ludzi, ujednoliconymi wymaganiami dla czasopism biomedycznych oraz z zasadami etycznymi określonymi w Porozumieniu z Farmington w 1997 r. 


\section{References/Piśmiennictwo}

1. Hall WD, Patton G, Stockings E, Weier M, Lynskey M, Morley KI, et al. Why young people's substance use matters for global health. The Lancet Psychiatry 2016; 3(3): 265-79.

2. Sierosławski J. Używanie narkotyków i alkoholu przez młodzież szkolna. Raport z badania ESPAD 2015 r. Warszawa: KBPN, PARPA, IPiN; 2015.

3. Malczewski A. Młodzież a substancje psychoaktywne. In: Grabowska M, Gwiazda M (eds.). Młodzież 2018. Warszawa: CBOS; 2019, p. 234-49. https://www.cinn.gov.pl/portal?id=166545 [Access: 24.08.2019].

4. Stockings E, Hall WD, Lynskey M, Morley KI, Reavley N, Strang J, et al. Prevention, early intervention, harm reduction, and treatment of substance use in young people. The Lancet Psychiatry 2016; 3(3): 280-96.

5. Currie K, Bray I. Health inequalities, risky behaviours and protective factors in adolescents: an analysis of secondary survey data from the UK. Public Health 2019; 170: 133-9.

6. Okulicz-Kozaryn K, Bobrowski K. Czynniki ryzyka, czynniki chroniące i indeksy tych czynników w badaniach nad zachowaniami problemowymi nastolatków. Alkoholizm i Narkomania 2008; 21(2): 173-199.

7. Kędzierski P, Kulesza J. Analiza przyczyn umieszczania dzieci i młodzieży w placówkach resocjalizacyjnych $i$ socjoterapeutycznych. Warszawa: Pracownia Resocjalizacji CMPPP; 2008.

8. Rustecka-Krawczyk A. W poszukiwaniu czynników chroniących młodzież z grupy ryzyka. Dziecko Krzywdzone. Teoria, badania, praktyka 2012; 11(3): 46-61.

9. Pisarska A, Bobrowski KJ, Greń J, Ostaszewski K. Risk and protective factors associated with alcohol and other psychoactive substance use among students attending youth correctional centres: study design and methodology. Alcohol Drug Addict 2019; 32(4): 247-66.

10. Pawliczuk W, Kaźmierczak-Mytkowska A, Srebnicki T, Wolańczyk T. Rozpowszechnienie zaburzeń psychicznych wśród dzieci i młodzieży przebywających w placówkach opiekuńczo-wychowawczych, domach dziecka - przegląd badań epidemiologicznych. Psychiatr Pol 2018; 52(2): 345-53.

11. Mazur J, Małkowska-Szkutnik A (eds.). Zdrowie uczniów w 2018 roku na tle nowego modelu badań HBSC. Warszawa: Instytut Matki i Dziecka; 2018.

12. Ostaszewski K. Używanie substancji innych niż alkohol. In: Ostaszewski K, Bobrowski K, Borucka A, Okulicz-Kozaryn K, Pisarska A, Biechowska D, et al. (eds.) Monitorowanie zachowań ryzykownych, zachowań natogowych i problemów zdrowia psychicznego 15-letniej mtodzieży: Badania mokotowskie 2004-2016. Badania ukraińskie, obwód lwowski 2016. Warszawa: Instytut Psychiatrii i Neurologii; 2017, p. 21-37.

13. Bobrowski K. Rozpowszechnienie używania substancji psychoaktywnych wśród młodzieży gimnazjalnej w Iławie, 2001-2005-2010. Alkoholizm i Narkomania 2012; 1: 37-56.

14. Modrzejewska R, Bomba J. Rozpowszechnienie używania substancji psychoaktywnych przez dzieci i młodzież a występowanie objawów depresyjnych. Przegl Lek 2004; 61(11): 1217-23.

15. Modrzejewska R, Bomba J. Rozpowszechnienie zaburzeń psychicznych i używania substancji psychoaktywnych w populacji 17-letniej młodzieży wielkomiejskiej. Psych Pol 2010; 44(4): 579-92.

16. McCrystal P. Drug prevention for young people with social, emotional and behavioural difficulties attending special education provision. Emotional and Behavioural Difficulties 2008; 13(4): 305-14.

17. Johnson KE, Taliaferro LA. Health behaviors and mental health of students attending alternative high schools: A review of the research literature. Journal for Specialists in Pediatric Nursing 2012; 17(2): 79-97.

18. Clement C, Thirlaway K, Smith A, Williams J. Vulnerable young people and alcohol use: a qualitative exploration. Journal of Substance Use 2014; 19(1-2): 112-7.

19. Kepper A, Monshouwer K, Van Dorsselaer S, Vollebergh W. Substance use by adolescents in special education and residential youth care institutions. European Child \& Adolescent Psychiatry 2011; 20(6): 311-9. 
20. Kepper A, Van Den Eijnden R, Monshouwer K, Vollebergh W. Understanding the elevated risk of substance use by adolescents in special education and residential youth care: the role of individual, family and peer factors. European Child \& Adolescent Psychiatry 2014; 23(6): 461-72.

21. Henderson M, Nixon C, McKee MJ, Smith D, Wight D, Elliott L. Poly-substance use and sexual risk behaviours: a cross-sectional comparison of adolescents in mainstream and alternative education settings. BMC Public Health 2019; 19(1): 564.

22. Grunbaum JA, Lowry R, Kann L. Prevalence of health-related behaviors among alternative high school students as compared with students attending regular high schools. Journal of Adolescent Health 2001; 29(5): 337-43.

23. Johnson KE, McMorris BJ, Kubik MY. Comparison of health-risk behaviors among students attending alternative and traditional high schools in Minnesota. The Journal of School Nursing 2013; 29(5): 343-52.

24. Denny S, Clark T, Watson P. The health of alternative education students compared to secondary school students: a New Zealand study. New Zealand Medical Journal 2004; 117(1205): U1147.

25. Lee A, Tsang CK, Lee SH, To CY. A YRBS survey of youth risk behaviors at alternative high schools and mainstream high schools in Hong Kong. Journal of School Health 2001; 71(9): 443-7.

26. Backović D, Marinković JA, Grujlčić-Šipetić S, Maksimović M. Differences in substance use patterns among youths living in foster care institutions and in birth families. Drugs: Education, Prevention and Policy 2006; 13(4): 341-51.

27. Ostaszewski K, Rustecka-Krawczyk A, Wójcik M. Czynniki chroniace i czynniki ryzyka zwiazane z zachowaniami problemowymi warszawskich gimnazjalistów: klasy I-III. Warszawa: Instytut Psychiatrii i Neurologii; 2011.

28. Weller NF, Tortolero SR, Kelder SH, Grunbaum JA, Carvajal SC, Gingiss PM. Health risk behaviors of Texas students attending dropout prevention/recovery schools in 1997. Journal of School Health 1999; 69(1): 22-8.

29. Pisarska A, Okulicz-Kozaryn K. Używanie substancji psychoaktywnych przez niemieszkających z rodzicami i nieuczących się nastolatków. Alkoholizm i Narkomania 2008; 4: 443-56.

30. Oleszkowicz A, Senejko A. Dorastanie. In: Trempała J (ed.). Psychologia rozwoju cztowieka. Warszawa: Wydawnictwo Naukowe PWN; 2011, p. 259-286.

31. Sierosławski J. Używanie alkoholu i narkotyków przez młodzież szkolnq. Raport z ogólnopolskich badań ankietowych zrealizowanych w 2003 roku. Warszawa: Instytut Psychiatrii i Neurologii; 2003 (typescript).

32. Bobrowski KJ, Greń J, Ostaszewski K, Pisarska A. Factors related to the alcohol use among students attending youth correctional centres. Alcohol Drug Addict 2019, 32(4): 317-36.

33. Rozporządzenie Ministra Edukacji Narodowej z dnia 11 sierpnia 2017 r. w sprawie publicznych placówek oświatowo-wychowawczych, młodzieżowych ośrodków wychowawczych, młodzieżowych ośrodków socjoterapii, specjalnych ośrodków szkolno-wychowawczych, specjalnych ośrodków wychowawczych, ośrodków rewalidacyjno-wychowawczych oraz placówek zapewniających opiekę i wychowanie uczniom w okresie pobierania nauki poza miejscem stałego zamieszkania (Dz. U. 2017, poz. 1606).

34. Loeber R, Keenan K. Interaction between conduct disorder and its comorbid conditions: Effects of age and gender. Clinical Psychology Review 1994; 14(6): 497-523.

35. Nowe narkotyki w Polsce 2017-2018. Raport Gtównego Inspektora Sanitarnego. Warszawa: Państwowa Inspekcja Sanitarna; 2019. www.gis.gov.pl [Access: 17.09.2019].

36. Pisarska A, Moskalewicz J, Corazza O, Assi S, Simonato P, Demetrovics Z, et al. Nowe substancje psychoaktywne - wiedza i doświadczenia polskiej młodzieży. Alkoholizm i Narkomania 2013; 26(3): 275-94. 